\title{
Earthworm (Eisenia fetida) Mucus Inspired Bionic Fertilizer to Stimulate Maize (Zea mays L.) Growth
}

\author{
Zhihong Zhang ${ }^{1}$, Yali Wu ${ }^{2,3}$, Vi Khanh Truong ${ }^{4} \mathbb{C}$ and Dongguang Zhang ${ }^{2,3, *}$ \\ 1 Faculty of Agriculture and Food, Kunming University of Science and Technology, Kunming 650500, China; \\ zhihong.zhang@kust.edu.cn \\ 2 College of Mechanical and Vehicle Engineering, Taiyuan University of Technology, Taiyuan 030024, China; \\ wuyali@tyut.edu.cn \\ 3 Key Laboratory of Soil Environment and Nutrient Resources of Shanxi Province, Taiyuan 030801, China \\ 4 School of Science, STEM College, RMIT University, Melbourne, VIC 3001, Australia; \\ vi.khanh.truong@rmit.edu.au \\ * Correspondence: zhangdongguang@tyut.edu.cn; Tel.: +86-0351-6014-008
}

Citation: Zhang, Z.; Wu, Y.; Truong, V.K.; Zhang, D. Earthworm (Eisenia fetida) Mucus Inspired Bionic Fertilizer to Stimulate Maize (Zea mays L.) Growth. Sustainability 2021, 13, 4299. https://doi.org/10.3390/ su13084299

Academic Editor: Alexandra Jacquelyn Burgess

Received: 24 February 2021

Accepted: 9 April 2021

Published: 13 April 2021

Publisher's Note: MDPI stays neutral with regard to jurisdictional claims in published maps and institutional affiliations.

Copyright: (c) 2021 by the authors Licensee MDPI, Basel, Switzerland. This article is an open access article distributed under the terms and conditions of the Creative Commons Attribution (CC BY) license (https:// creativecommons.org/licenses/by/ $4.0 /)$.
Abstract: Background: Increasing population and food consumption are placing unprecedented demands on crop production. Maize is one of the most important food crops in the world, the improvement of its yield primarily depends on the application of chemical fertilizer. Methods: Earthworm activity is an essential factor in promoting soil fertility and stimulating plant growth. Inspired by amino acids composition of earthworm (Eisenia fetida) epidermal mucus, the liquid fertilizer was developed and prepared by utilizing a bionic approach. The influence of earthworm epidermal mucus (mucus), the mucus-mimicked mixture of amino acids (bionic fertilizer) and urea fertilizer (urea) on maize emergence and growth were studied and compared with the control group (distilled water). Experimental cultivation tests were conducted. The aforementioned three types of liquid fertilizer effects on maize seed vigor index, seedling emergence rate and plant quality were quantitatively evaluated. Results: Based on the conducted research, it was found that the beneficial effects of different fertilizers for maize emergence rate were ranked as follows: mucus > bionic fertilizer $>$ urea. The low concentration treatments were beneficial to the maize emergence, while the high concentration treatments were helpful to the maize growth and root development. Besides, the lower concentration of mucus was the most effective fertilizer treatment for improving seedling quality. In addition, the test results of three types of liquid fertilizer effects on maize growth indicated that the higher concentration treatments provided more nitrogen nutrition than lower concentration treatments. Furthermore, the maize stem height and diameter were significantly promoted $(p<0.05)$ by the three types of liquid fertilizer. The beneficial influences of liquid fertilizer treatments for plant height, stem diameter, relative chlorophyll content and photosynthetic characteristic of leaves were ranked as follows: bionic fertilizer $>$ urea $>$ mucus. Conclusions: Bionic fertilizer demonstrated significant beneficial fertilizing effects $(p<0.05)$, which increased soil nutrients, improved maize physiological parameters, promote its growth and improved dry matter accumulation. The tested results verified the effectiveness of bionic fertilizer on stimulating maize growth.

Keywords: bionic; liquid fertilizer; soil animal; earthworm; epidermal mucus; maize; soil nutrients

\section{Introduction}

Increasing population and consumption are placing unprecedented demands on agriculture. To meet the world's future food security and sustainability needs, food production needs to grow substantially [1]. However, increase in the cultivable area is remarkably slow [2]. The rapidly growing population and slowly expanding cultivated land necessitate the extensive application of fertilizers [3]. The widespread application of chemical fertilizer is the promising approach to improve crop yield [4,5]. Within the past century, a dramatic growth in crop production mainly contributed to fertilization has 
been observed, which results in an increased availability of plant nutrients [6]. Nowadays, chemical fertilizer accounts for about $40-60 \%$ of total increase in crop production [7]. Maize is one of the most important food crops in the world and provides at least $30 \%$ of the food calories to more than 4.5 billion people in 94 developing countries [8]. It is also a key ingredient in animal feed and is used extensively in industrial products, including the production of biofuels [8]. Increasing demand and production shortfalls in global maize supplies have worsened the market, contributed to surging global maize prices, and even threatened the food insecurity for millions of populations [3]. Measures are needed to be taken to address these challenges and accelerate maize growth and yield $[7,8]$.

In agricultural systems, soil organisms have played significant roles in soil structure, water content, temperature and nutrient cycling [9-14]. Soil organisms also have been well recognized to have the potential in modifying soil fertility and improving plant growth [15-18]. The interactions between plants and soil organisms are essential for nutrient uptake by plants. Among various soil organisms, the importance of earthworms for soil fertility has been stated as far back to Darwin [19]. Earthworms burrow through soil and feed on organic material, therefore changing the environment of all other soil-inhabiting organisms, including plant roots $[9,20-25]$. Through the soil burrowing and foraging activities of earthworms, desired soil physical, structural conditions for plant root growth could be created [26]. Not only in soil structure, earthworms also have been considered to be one of the essential components of the soil biota in terms of maintenance of soil fertility. Evidence increasingly showed that earthworms play a beneficial role in agro-ecosystems [27]. Many researchers have reported that earthworms can have important influences on physical and biological effects that affect the nutrient supply to plants, therefore improving plant growth [22,28-32]. Earthworms are also known to contribute to the aggregate stability of soils varying in texture, carbonate and concentration of organic matter by burrowing, foraging and casting on the soil surface and within the soil [33-37]. It has been proved that earthworm could modify the structure, microbial activity and nutrient mineralization in soils [12,38-42]. Earthworms could also affect the plant growth through changing the spatiotemporal availability of carbon $(C)$, nitrogen $(N)$ and phosphorus $(P)$ nutrients in their casts and burrow walls [43-46]. Whalen et al. [47] indicated that earthworms contribute to $N$ cycling in maize agro-ecosystems through excretion processes. Bhadauria and Ramakrishnan [48] found that earthworms participated in the $N$ cycle through worm cast egestion, mucus production and dead tissue decomposition. Some studies have shown that the biological interaction of arbuscular mycorrhizal fungi (Glomus intraradices) and earthworm interactively increased maize shoot and root biomass through their regulation of soil enzyme activities and on the content of available soil $N, P$ and $K[13,49,50]$. Since the growth of plant requires the nutrient supply of both $N$ and $P$ in soils [45], earthworms and fungi interactions may have contributed to regulating plant growth in the environment where soil nutrients are limited [51].

Earthworm mucus from its epidermal layer plays a crucial role in locomotion, feeding, osmoregulation, defense, reproduction and protection of epithelial and other surfaces $[21,52,53]$. It has been well known that mucus was able to enhance activities of soil microbes [39]. Through hydroponic experiment, it was found that earthworm mucus significantly enhanced tomato seedlings growth by increasing $C d$ uptake and transport in plants [54]. Moreover, earthworms influence the supply of nutrients in several ways. Not only is earthworm tissue and material enriched in specific nutrients, relative to the soil matrix, but also ingestion of organic material increases the rate of cycling [20]. It has been proved that earthworm and its mucus could accelerate maize stover stabilization by activating lignocellulose degrading microbes during the vermicomposting process [55,56]. Bityutskii et al. [57] also found that earthworm mucus as a waste product of these invertebrates remaining in the soil could drive mineralization and humification of plant residues. Moreover, earthworm mucus excretion was known to facilitate soil aggregates and nutrients properties and processes (physically, chemically and biologically). Earthworms are key as an organic soil fertilizing factor to promote many crop growth and developments 
in comparison to synthetic chemical fertilizers which have been known to lead to more impoverished soil conditions and its natural fertility over long time usage [58]. Amino acids are one of the significant components of earthworm mucus [53,59]. Exogenous amino acids are known to promote essential element uptake by plants [60-62]. Glutamate is one of the major components in both mucus and bionic fertilizer. Glutamate is known to be the critical factor for seed emergence, plant growth, development and response to environmental stresses [63]. Glycine is the components in the earthworm mucus and bionic fertilizer. The application of glycine was reported to provide the increase of ureides in field conditions with the consequent production of urea and increased urease activity [64].

A sustainable agriculture strategy demands the implementation of multidirectional actions that combine productive aims of agriculture with environmental protection requirements [65]. In the natural world, through millions of years of evolution and rigorous process of natural selection, biological organisms have gradually developed exceptional functions and characteristics highly adaptable to their living environments [66]. The interactions of living organisms with natural surroundings have led to the evolution of biological systems and environmental adaptabilities $[67,68]$. Biological organisms have achieved a variety of biological functions efficiently by using the synergic actions and demonstrate optimal adaptations to the living environment [69]. Bionics is the comprehensive science which imitates the biological principles to construct technology systems or makes artificial technology systems which have the characteristics of biology [40,70-76]. Either earthworm mucus or amino acids could significantly promote plant growth, implying that earthworm epidermal mucus could serve as a type of amino acid liquid fertilizer which provides nutrients to plants [59]. From the bionic perspective, the composition of earthworm mucus provides valuable inspiration for potential simulation and preparation of liquid fertilizer. In order to enhance soil fertility and implementing of fertilization, it is necessary to study the effects of earthworm epidermal mucus on the growth of plants. Most of the exceptional functionality of biological materials is due to their chemical compositions. Hereby the aspect of bionic emerges, by learning from chemical compositions biological materials, their component content could be simulated and reconstructed [77]. Researchers have studied the amino acid composition of earthworm epidermal mucus which is considered to be the basic unit of synthetic protein [53]. The amino acid applied to the soil could be directly absorbed by the plants, or further decomposed by the action of microorganisms. Amino acids have been proven to have the characteristics of less residual soil and enhanced physiological activity of the crop [78,79].

In this study, inspired by earthworm epidermal mucus as the natural evolution result, and learning from composition and proportion of amino acids in the Eisenia foetida epidermal mucus, bionic fertilizer was designed and prepared. By studying the effects of epidermal mucus, bionic fertilizer, conventional urea fertilizer and distilled water (used as control) solutions on the growth of maize (Zea mays L.) from the emergence stage to the jointing stage, effectiveness of different fertilizers was determined and compared. Further, the impacts of the fertilizers on soil fertility were investigated after treatments.

\section{Materials and Methods}

\subsection{Sample Collection and Analysis of Nitrogen Content of Earthworm Epidermal Mucus}

The epigeic species of Eisenia fetida were selected for this study because this species is widely distributed in the world and has been commonly fed and used in laboratory experiments [80]. Moreover, Mokgophi et al. [29] found E. fetida have great potential to be used to improve soil fertility and thus reduce the use of synthetic fertilizers in crop production; Raza et al. [81] indicated E. fetida as ecological engineers that help to enhance reactive nutrients in a sustainable way; Wen et al. [82] demonstrated that Eisenia fetida has beneficial effects on the bioavailability of rare earth elements in soil, thereby increased biomass of wheat shoots and roots.

In addition, these earthworms were collected without compromising the survival of their species. Samples of live Eisenia fetida were collected from an earthworm farm 
$\left(43^{\circ} 52^{\prime} \mathrm{N}, 125^{\circ} 19^{\prime} \mathrm{E}\right)$, in Changchun City, Jilin province, China. The epidermal mucus was extracted and collected by using the electrical stimulation device [53]. Based on the composition and content of amino acids in the mucus, the composition ratio of various amino acids was determined, as shown in Supplementary Materials Table S1. Based on the molecular weight of the amino acid and the atomic weight of nitrogen in the amino acid, the mass ratio of nitrogen atoms in amino acids was calculated. Then, the calculated value was combined with the ratio of the amino acid components and given in Supplementary Materials Table S1. In addition, the nitrogen contents of the mucus amino acids of Eisenia foetida were presented in Supplementary Materials Table S2.

According to the result of Supplementary Materials Table S2, it was determined that the nitrogen content of amino acids in the mucus of Eisenia foetida was $14.78 \mathrm{wt} . \%$. Since the nitrogen in earthworm mucus was mainly derived from protein and free amino acid, the protein hydrolysate was also an amino acid, and the content of amino acid in $100 \mathrm{~g}$ of Eisenia fetida epidermal mucus was calculated to be $0.735 \mathrm{~g}$. According to Supplementary Materials Tables S1 and S2, the nitrogen ratio and nitrogen content of the Eisenia fetida epidermal mucus were calculated by the following equation:

$$
N=M \times c=M \times a \times b=100 \times \frac{0.735}{100} \times 0.148=0.11,
$$

where in $N$ is the nitrogen content of the Eisenia foetida epidermal mucus (g); $M$ is the mass of the earthworm mucus (g); $c$ is the nitrogen content of the mucus, $c=a \times b$; a is the proportion of amino acids in the mucus; $b$ is the proportion of nitrogen in the amino acid.

It could be determined from the estimation of Equation 1 that the nitrogen content of the Eisenia foetida epidermal mucus was $0.11 \mathrm{wt} . \%$, and the nitrogen content of the $100 \mathrm{~g}$ mucus was $0.11 \mathrm{~g}$.

\subsection{Formula Design of Bionic Fertilizer Mixtures}

Based on the proportion of amino acids, the component quality of the solid substance of the bionic fertilizer could be prepared. However, the total amount of the amino acid should be determined based on the amount of nitrogen used in the selected crop varieties at different fertilization stages. The maize hybrid Xianyu335 (jointly produced by Pioneer Corp of Grandview, Washington, DC, USA and Shandong Denghai Seed Corp of Yantai, Shandong, China) with the characteristic of high yield and suitable of machine-harvesting that widely cultivated field crop maize in China, was used as the test object in the current study [83-86]. The effects of earthworm epidermal mucus and bionic liquid fertilizer on the growth of maize from seedling stage to jointing stage and soil nutrient content were studied, and the fertilizing effect of the above-mentioned liquid fertilizer was investigated. According to the current research results, the appropriate nitrogen content for planting maize in northeast China was $330 \mathrm{~kg} / \mathrm{hm}^{2}, 40 \%$ of which is the base fertilizer in the maize seedling stage, $60 \%$ was the topdressing fertilizer in the maize ear stage, and the planting density of maize was $6 \times 10^{4} \mathrm{plant} / \mathrm{hm}^{2}$. According to the above data, the suitable amount of nitrogen in the whole growth stage of maize was $5.5 \mathrm{~g} / \mathrm{plant}$, and the suitable amount of nitrogen in the seedling stage was $2.2 \mathrm{~g} /$ plant.

Pure urea with a nitrogen content of $46.67 \mathrm{wt} . \%$ is the most commonly used conventional nitrogen fertilizer in agronomic fertilization. It is currently considered to be the nitrogen fertilizer with the highest nitrogen content. Due to the high solubility of pure urea, it is also commonly used as a liquid chemical nitrogen fertilizer. Plants tend to absorb amino acids actively. In the cultivated soil with rich organic matter, microorganisms promote life activities by absorbing amino acids; on the other hand, microorganisms also decompose soil organic matter and provide nutrition for crops. In this study, amino acid bionic liquid fertilizer was prepared based on the principle that has the same nitrogen content as that of urea. The amount of amino acid applied to the soil under the same fertilization treatment (nitrogen ratio $14.78 \mathrm{wt} . \%$ ) should be 3.16 times that of urea (nitrogen ratio $46.67 \mathrm{wt} . \%)$. Only the base fertilizer required for the maize seedling stage was tested, 
and no additional fertilizer was applied. The experimental period of maize included both stages of maize emergence and seedling. Based on the total amount of suitable nitrogen elements required for the maize test stage (seed stage) of $2.2 \mathrm{~g} / \mathrm{plant}$, and then the nitrogen content of the two fertilizers was calculated separately, the total amount of urea required for the experimental maize period was $4.7 \mathrm{~g} /$ plant. The total amount of amino acids was $14.9 \mathrm{~g} /$ plant (approximately $15 \mathrm{~g} /$ plant).

According to the requirements of the national agricultural industry-standard of China "NY 1429-2010 water-soluble fertilizer containing amino acid "the content of amino acid solid matter in the solution should not be less than $10 \mathrm{wt} . \%$. Therefore, the total mass of the bionic liquid fertilizer solution applied to the suitable maize seedling stage should not be over $150 \mathrm{~g} /$ plant, and the amino acid reliable content should not be less than $15 \mathrm{~g}$. The liquid fertilizer sample preparation and application processes are shown in Figure 1.

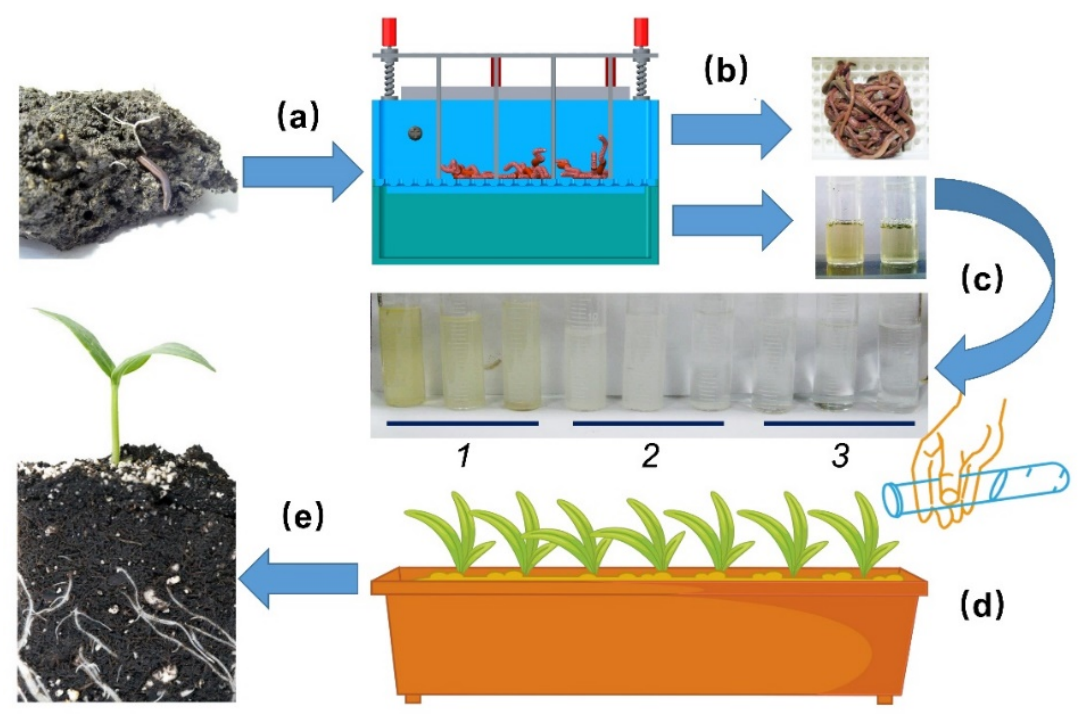

Figure 1. Liquid fertilizer sample preparation and application processes. (a) Eisenia foetida collection; (b) epidermal mucus extraction; (c) liquid fertilizer samples preparation, 1-earthworm epidermal mucus, 2-bionic liquid fertilizer, 3-urea fertilizer; (d) fertilizer addition; (e) growth tests.

Based on the criteria mentioned above, the fertilization treatment of liquid fertilizer within the maize experimental stage was determined as follows:

(1) $150 \mathrm{~g} /$ plant of bionic fertilizer with an amino acid content of $10 \mathrm{wt} . \%$ was adopted as bionic fertilizer 1; mucus of Eisenia fetida with same solution mass as bionic fertilizer was adopted as mucus treatment 1 . Urea and the bionic fertilizer had the same nitrogen content. The mucus, bionic fertilizer and urea were all set to have five fertilization treatments with the same solution mass. The concentration of the first fertilization treatment was the highest, and the concentration of the latter fertilization treatment was half of the previous concentration (diluted twice). The total amount of solute of the three liquid fertilizers used during the maize test stage is shown in Table 1.

(2) The total amount of the above three types of liquid fertilizer was distributed to two stages of maize emergence stage and seedling growth stage. Since the maize emergence stage is a slow absorption stage for nitrogen fertilizer, $20 \mathrm{wt} . \%$ ( $30 \mathrm{~g} / \mathrm{plant})$ of the above solution is applied during the maize emergence stage, and $80 \mathrm{wt} . \%$ (120 g/plant) of the above solution is applied in the maize seedling stage.

(3) Different concentrations of mucus, bionic fertilizer, urea and distilled water were applied to maize plants, and the effects of mucus and bionic fertilizer on soil fertility were investigated. Extraction of $150 \mathrm{~g}$ of mucus using an electrical stimulation method requires approximately $1000 \mathrm{~g}$ of Eisenia fetida. 
Table 1. Total solute content of three liquid fertilizer treatments during maize test stage *.

\begin{tabular}{|c|c|c|c|c|c|}
\hline $\begin{array}{c}\text { Fertilization } \\
\text { Treatment }\end{array}$ & $\begin{array}{l}\text { Mucus } \\
\text { Dosage } \\
\text { g/Plant }\end{array}$ & $\begin{array}{c}\text { Fertilization } \\
\text { Treatment }\end{array}$ & $\begin{array}{c}\text { Amino Acid } \\
\text { Dosage } \\
\text { (g/Plant) }\end{array}$ & $\begin{array}{c}\text { Fertilization } \\
\text { Treatment }\end{array}$ & $\begin{array}{l}\text { Urea Dosage } \\
\text { (g/Plant) }\end{array}$ \\
\hline mucus 1 & 150.00 & $\begin{array}{c}\text { bionic } \\
\text { fertilizer } 1\end{array}$ & 15.00 & urea 1 & 4.70 \\
\hline mucus 2 & 75.0 & $\begin{array}{c}\text { bionic } \\
\text { fertilizer } 2\end{array}$ & 7.50 & urea 2 & 2.35 \\
\hline mucus 3 & 37.50 & $\begin{array}{c}\text { bionic } \\
\text { fertilizer } 3\end{array}$ & 3.75 & urea 3 & 1.18 \\
\hline mucus 4 & 18.75 & $\begin{array}{l}\text { bionic } \\
\text { fertilizer } 4\end{array}$ & 1.87 & urea 4 & 0.59 \\
\hline mucus 5 & 9375 & $\begin{array}{c}\text { bionic } \\
\text { fertilizer } 5\end{array}$ & 0.94 & urea 5 & 0.29 \\
\hline
\end{tabular}

* The dosage of each solution treated with liquid fertilizer in the table was $150 \mathrm{~g}$.

\subsection{Investigation of Effects of Liquid Fertilizers on Maize during the Emergence Stage}

The investigation of the fertilizing effects of different liquid fertilizers on the emergence stage of maize were carried out in the modern solar greenhouse of the College of Biological and Agricultural Engineering of Jilin University, Changchun, China. During the whole test stage, the greenhouse was naturally ventilated, with an average daily temperature of $23^{\circ} \mathrm{C}$. The basic physical properties of maize seeds are shown in Table 2.

Table 2. Basic physical properties of maize seeds *.

\begin{tabular}{ccccc}
\hline \multirow{2}{*}{ Variety } & \multirow{2}{*}{$\mathbf{1 0 0}$ Weight $(\mathbf{g})$} & \multicolumn{3}{c}{ Triaxial Size $(\mathbf{m m})$} \\
\cline { 3 - 5 } & & $\boldsymbol{L}$ & $\boldsymbol{W}$ & $\boldsymbol{H}$ \\
\hline Xianyu 335 & $28.60 \pm 0.60$ & $10.03 \pm 1.19$ & $7.84 \pm 0.69$ & $5.83 \pm 1.20$ \\
\hline
\end{tabular}

* The data in the table indicates the mean and \pm standard deviation of the measurements.

A total of 800 maize seeds were randomly selected, and each maize was sown in the nursery and covered with the substrate soil. The sowing depth of the maize in the nursery was controlled to be $3 \mathrm{~cm}$. Then, $20 \mathrm{~kg}$ of Eisenia fetida were acquired in the Nanguan District earthworm farm $\left(43^{\circ} 87^{\prime} \mathrm{N}, 125^{\circ} 34^{\prime} \mathrm{E}\right)$ in Changchun City. Then, earthworm mucus was extracted and collected by electrical stimulation method. As shown in Table 3, according to the formula preparation principle, three liquid fertilizers of mucus, bionic fertilizer and urea were prepared and set as totally 5 fertilization treatments. Each fertilization treatment corresponds to 50 maize seeds in the nursery. Liquid fertilizer treatment is applied to the nursery, and distilled water was set as the control group (corresponding to 50 maize seeds).

Table 3. Three liquid fertilizer fertilization treatments in maize seedling stage *.

\begin{tabular}{cccccc}
\hline $\begin{array}{c}\text { Fertilization } \\
\text { Treatment }\end{array}$ & $\begin{array}{c}\text { Mucus } \\
\text { Dosage } \\
\text { g/Plant }\end{array}$ & $\begin{array}{c}\text { Fertilization } \\
\text { Treatment }\end{array}$ & $\begin{array}{c}\text { Amino Acid } \\
\text { Dosage } \\
\text { (g/Plant) }\end{array}$ & $\begin{array}{c}\text { Fertilization } \\
\text { Treatment }\end{array}$ & $\begin{array}{c}\text { Urea Dosage } \\
\text { (g/Plant) }\end{array}$ \\
\hline mucus 1 & 30.00 & $\begin{array}{c}\text { bionic } \\
\text { fertilizer 1 } \\
\text { bionic } \\
\text { fertilizer 2 } \\
\text { bionic } \\
\text { fertilizer 3 } \\
\text { bionic }\end{array}$ & 3.00 & urea 1 & 0.94 \\
mucus 3 & 15.00 & 0.75 & urea 2 3 & 0.47 \\
mucus 4 & 7.50 & $\begin{array}{c}\text { fertilizer 4 } \\
\text { bionic } \\
\text { fertilizer 5 }\end{array}$ & 0.19 & urea 4 & 0.12 \\
mucus 5 & 1.88 & urea 5 & 0.06 \\
\hline
\end{tabular}

\footnotetext{
* The dosage of each solution treated with liquid fertilizer in the table was $30 \mathrm{~g}$.
} 
The emergence of maize seeds was observed on a daily basis, the indexes and indicators were logged and the soil moisture on the surface of the nursery was kept. As shown in Supplementary Materials Figure S1, a height of $2 \mathrm{~cm}$ of maize seedlings was set as the emergence standard.

The emergence rate, emergence index and seed vigor index were calculated by Equations (2)-(4):

$$
E=\frac{n}{N} \times 100 \%
$$

where $E$ is the emergence rate; $n$ is the number of emergences; $N$ is the total number of seeds.

$$
G I=\sum \frac{G t}{D t}
$$

where GI is the emergence index; $D t$ is the number of emergence days; $G t$ is the number of emergences within $D t$.

$$
V I=G I \times S,
$$

where VI is the seed vigor index; GI is the emergence index; $S$ is the dry weight of the seedlings on the sampling day.

When $80 \%$ of the maize seedlings grow to the four-leaf stage, the emergence of the maize seeds was considered to be accomplished. Three seedlings were randomly selected in the fertilization treatment of the above solution, rinsed with distilled water, then cut from the stems and roots of the seedlings by using scissors. The root length and surface area of individual maize seedlings were determined by using a root analysis system (WinRHIZO, Regent Instruments, Canada). The cut leaves and roots of the cut seedlings were placed in a constant temperature drying oven at $105^{\circ} \mathrm{C}$ for $10 \mathrm{~min}$, then dried at $80{ }^{\circ} \mathrm{C}$ to balance weight, the dry weight of the stems and the dry weight of the roots were measured and the root to crown ratio was calculated by Equation (5):

$$
K=M_{l} / M_{r}
$$

where $K$ is the root to shoot ratio; $M_{1}$ is the root dry weight; $M_{\mathrm{r}}$ is the stem dry weight.

\subsection{Investigation of Effects of Liquid Fertilizers on Maize within the Growth Stage}

From the four-leaf stage to the jointing stage, maize undergoes root development, leaf growth and stem segmentation. From the four-leaf stage, the maize seedlings turned from seed autotrophic to external heterotrophic, and the roots gradually began to absorb soil nutrients, and the leaves strengthened their participation in photosynthesis. The experiments on the effects of different liquid fertilizers on the growth of maize seedlings were carried out. The changes in soil nutrient and maize plant growth during the four-leaf stage to the jointing stage of maize were investigated.

In order to reduce the impact of maize seedling emergence differences on the growth stage of maize, the maize seeds were first cultivated to the four-leaf stage. Then, healthy and uniform seedlings were transplanted into the greenhouse soil. The tested soil in the greenhouse is the natural northeast black soil and contains humus. The physical properties and nutrient contents of the cultivated layer soil are shown in Supplementary Materials Table S3.

Initially, soil in the greenhouse was carefully ploughed to reduce the impact of soil unevenness on the test. The application of liquid fertilizer was completely randomized, and the mucus, bionic fertilizer and urea treatment were repeated four times. Maize seedlings that were not added with any fertilizer were used as controls. Combined with maize agronomic techniques and soil block division in the greenhouse, the maize planting layout and liquid fertilizer application plan are shown in Supplementary Materials Table S4. The planting layout of maize seedlings was 8 rows and 10 plants, the row spacing $L$ was $65 \mathrm{~cm}$ and the plant spacing $D$ was $30 \mathrm{~cm}$. 
Formulated bionic fertilizer and urea were prepared. A total of $7 \mathrm{~kg}$ of earthworm mucus were extracted and collected; three types of liquid fertilizers were prepared into five fertilization treatments, as shown in Supplementary Materials Table S5. According to the commonly used application scheme, liquid fertilizer was applied to the roots of the maize seedlings at the time of transplanting. The application position was in the soil range of $5 \mathrm{~cm}$ from the surface and about $10 \mathrm{~cm}$ in diameter of the maize roots, and then fertilizers were covered with soil. During the maize growth test stage, field management including watering and weeding, no additional fertilization was applicated.

Five days after transplanting, test indicators and indexes were measured. Between each measurement, the interval was ten days. The measurement was continued for six times, then data were recorded and analyzed. The test indicators and sampling methods are as follows.

(1) Soil nutrient content

The soil nutrient rapid tester was used to measure the content of ammonium nitrogen, rapid available potassium and phosphorus. Soil $\mathrm{pH}$ was measured by TPY-6A (Top Instrument Co., Ltd., Hangzhou, Zhejiang, China). Root-soil samples of all the maize plants corresponding to each treatment were taken separately and mixed as a sample to be tested. The measurement was repeated three times, and the average value was taken as the soil nutrient content corresponding to each treatment. The selected test and measurement instrument are shown in Supplementary Materials Figure S2.

(2) Maize growth index

The plant height of the maize was measured using a meter ruler, and the measurement range was the vertical distance from the stalk bottom to the tip of the blade. A vernier caliper measured the stalks of the maize, and the stalk was measured three times a week during the experiment, and the average value was taken as the stem diameter.

(3) Maize physiological indicators

The relative chlorophyll content (SPAD value) of maize leaves was non-destructively tested in the field using a SPAD-502 chlorophyll meter (Minolta Camera Co. Ltd., Osaka, Japan). The leaf base, leaf and tip of the middle leaves of each treatment and control group were selected and measured. After aforementioned repeated measurements, the average value was taken as the chlorophyll content of the plant. The average value of chlorophyll content of all maize plants treated by the same fertilization treatment was counted as the test result of the treatment.

Non-destructive detection of light and parameters of maize leaves in the field using portable photosynthetic tester (Model:LI-6400 XTLi-Cor Environmental, Lincoln, NE, USA), including net photosynthetic rate (Pn), stomatal conductance (Cond), transpiration rate (Trmmol) and leaf intercellular $\mathrm{CO}_{2}$ concentration (Ci). Middle leaves of each treatment and control maize plants were selected. The measurement was performed near the $1 / 3$ of the tip. The measurement time was between 9:00 a.m. and 11:00 a.m. on each day. If the weather of measurement day is rainy, the measurement is postponed for the next day. The same indicator of the same maize plant was repeatedly measured three times, and the average value was taken as the photosynthetic parameter. The average value of photosynthetic parameters of all maize plants treated by the same fertilization was counted as the test result.

\subsection{Data Analysis}

The impacts of earthworm epidermal mucus (mucus), the mucus-mimicked mixture of amino acids (bionic fertilizer), urea fertilizer (urea) and distilled water (control group) on maize seed vigor index, seedling emergence rate and plant quality were quantitatively evaluated by using a two-way ANOVA. The statistical analysis was performed by using Origin software 2020b edition. Before ANOVA analysis were conducted, data were tested for normality and homogeneity. Residual analysis was performed to test the assumptions 
of the two-way ANOVA. Outliers were assessed by inspection of a boxplot. Normality of data of each combination of the groups was assessed using Shapiro-Wilk's normality test. Homogeneity of variances was assessed by homogeneity tests (Levene's test). The produced residual plots were normally distributed with the mean with variances being homogeneous, which meets the assumptions of ANOVA. The differences of significant treatment means were further analyzed using a Tukey test at a 5\% significance level. Results were presented as mean \pm standard deviation. Graphs were prepared using Microsoft Office Excel software 2019 edition. Data were as mean \pm standard deviation.

\section{Results and Discussion}

\subsection{Effects on the Vigor of Maize Seeds}

The effects of different liquid fertilizer treatments on maize emergence rate and emergence index are shown in Figure 2 and Supplementary Materials Figure S3. Under the test conditions mentioned in the previous section, maize seeds began to emerge nine days after sowing. For each treatment, 50 seeds were randomly selected for the test. As can be seen from Figure $2 a$, for the three types of liquid fertilizers, the low concentration treatments (treatments 3, 4 and 5) were more favorable for promoting maize emergence than the high concentration treatments (treatments 1 and 2). Urea1 and urea2 treatments inhabited emergence and exhibited a lower emergence rate as compared with the control. On the first day of emergence, emergence rates of treatments urea1 and urea2 were found to be less than $2 \%$. However, mucus treatment was found to promote the emergence of maize. On the first day of emergence, the emergence rate reached 19.6\%. Mucus was reported to promote the secretion of auxins of plants, such as indoleacetic acid, which affects the metabolism of plant cells, thereby causing variations in growth and development [87].
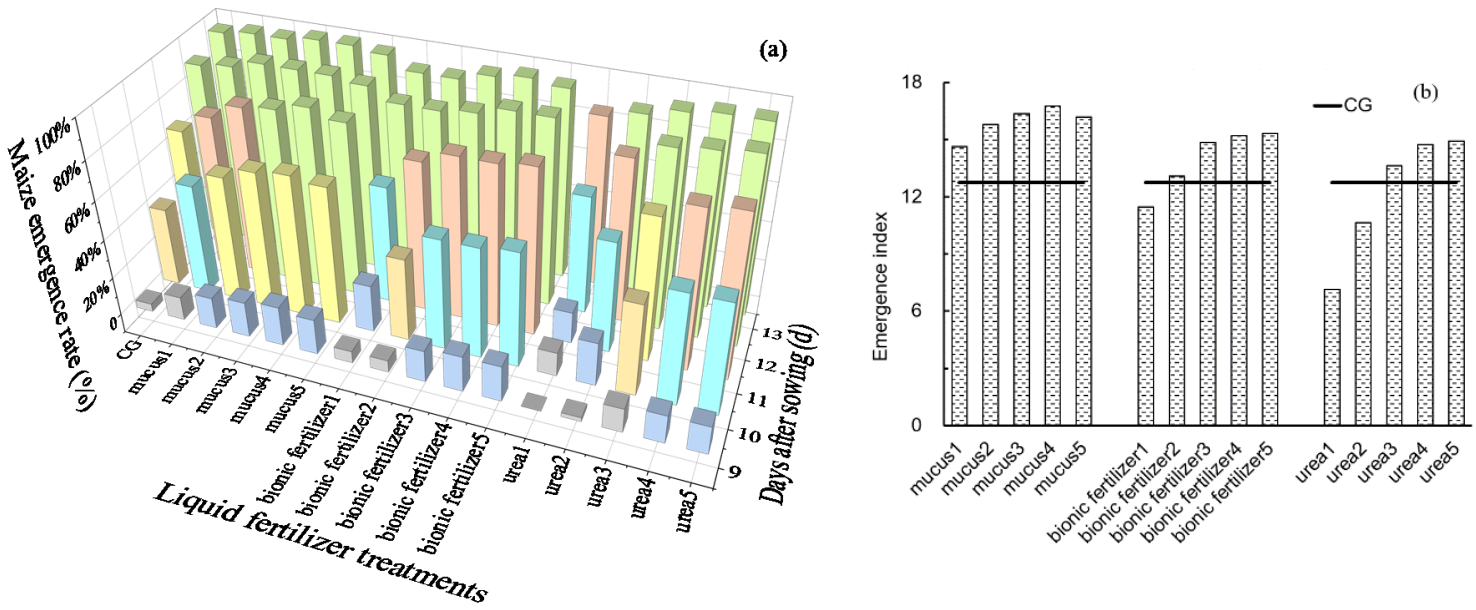

Figure 2. Effect of liquid fertilizer treatments on maize emergence rate and emergence index. (a) Maize emergence rate of 9-13 days after sowing; (b) Emergence index.

The emergence period was defined as the number of days when the emergence rate reaches $50 \%$. It can be seen from Figure $2 \mathrm{a}$, as compared with the $\mathrm{CG}$, all the mucus treatments have significant effects $(p<0.05)$ on the maize emergence rate, which all exceeded 55\%. It could be observed in Figure $2 \mathrm{a}$ that the seedling emergence time of maize seeds was ten days under the treatment of mucus. The bionic fertilizer and low concentration urea 3,4 and 5 treatment could promote maize emergence, but the high concentration of bionic fertilizer1, urea1 and 2 inhibited maize emergence. As can be seen from Figure $2 \mathrm{a}$, the seedling emergence rate of the $C \mathrm{G}$ reached $68 \%$, and it could be considered that the average emergence time of maize under the current test conditions was 11 days, and the emergence rate of each of the fertilization treatments of 3-5 was higher than that of the CG. It was proved that the low concentration of liquid fertilizer could enhance the vigor index of maize seeds and shorten the maize emergence time. As can be observed 
from Figure 2a, among the liquid fertilizers, mucus shortened the maize emergence time for one day, and showed a strong stimulating effect on maize seeds. The effect of the three liquid fertilizers on maize emergence was: mucus $>$ bionic fertilizer $>$ urea. It can be seen from the Figure 2a that the maize seedling rate of CG reached $90 \%$ on the 12th day after sowing. For all the treatments of mucus, bionic fertilizer and urea of 3-5, the emergence rates were improved as compared to the CG. The maize emergence rate of the control group reached $96 \%$ on the 13th day after sowing, and $87 \%$ of the seedlings grew to the four-leaf stage. The emergence of the maize was considered to be finished. As compared to the CG, for all the treatment of mucus, the emergence rate was greatly improved.

The emergence index reflects the period of time the maize seeds need to evenly emerge. The higher emergence index indicates that the maize seed evenly emerges in a shorter period of time. It can be seen from Figure $2 b$ that the emergence index of five mucus treatments, four bionic fertilizer treatments and three urea treatments was higher than that of the CG; the average emergence index of the mucus treatment was the highest, indicating that for the mucus treatment, maize seed emergence is most rapidly and evenly.

The vigor of maize seeds reflects the potential for rapid and even germination of seeds, and their growth into a seedling plant. The effect of liquid fertilizer treatments on the vigor of maize seeds is shown in Figure 3. Compared with the CG, for all the mucus treatment, bionic fertilizer and urea treatment of 3-5, the seed vigor index showed an upward trend, which indicated that the evenness and speed of maize seeds emerge was prompted. It was ensured that the maize seedlings are evenly and robust. These beneficial effects will be conducive for increasing the dry matter accumulation of crops and increasing crop yield.

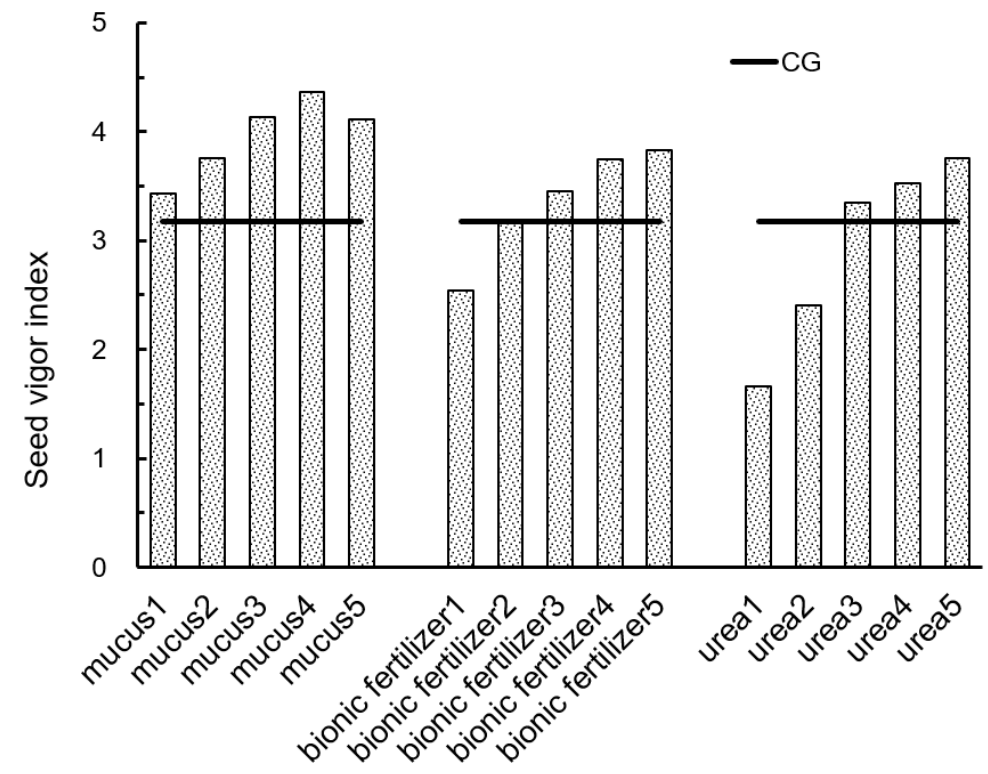

Figure 3. Effect of liquid fertilizer treatments on the vigor index of maize seeds.

\subsection{Effects on the Quality of Maize Seedingl Plants}

The plant height, stem diameter, dry weight and root-shoot ratio of maize seedlings under different fertilization treatments were investigated after emergence was completed (14 days after sowing). As shown in Figure 4, the effects of various fertilizer treatments on the quality of maize emergence were analyzed. As can be seen from Figure $4 \mathrm{a}, \mathrm{b}$, the control plant maize seedlings had a plant height of $9.10 \mathrm{~cm}$ and a stem diameter of $2.63 \mathrm{~mm}$. As compared with the CG, under five treatments of mucus, low concentration bionic fertilizer and urea $3-5$, the average plant height and stem diameter of maize seedlings exceeded the CG. 

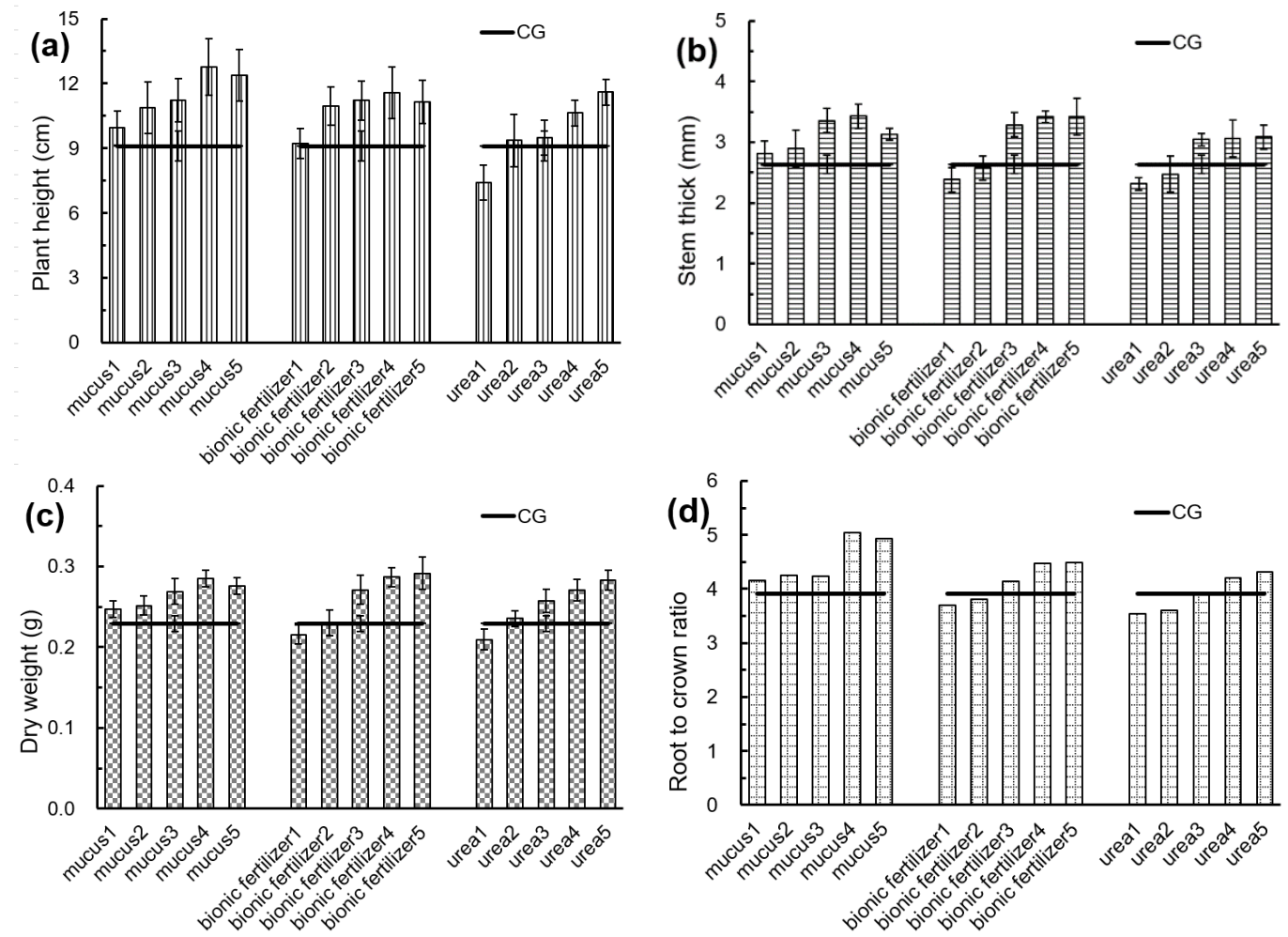

Figure 4. Effect of different liquid fertilizers on the quality of maize emergence. (a) Plant height; (b) Stem thick; (c) Dry weight; (d) Root-shoot ratio (The error bar represents standard error).

The dry weight of maize represents the dry matter accumulation of maize seedlings, and also indicates the ability of maize seed to accumulate and transform photosynthetic products during the growth stage. It can be observed from Figure $4 \mathrm{c}$ that the dry weight of the maize seedlings of CG was $0.23 \mathrm{~g}$. As compared with the CG, five mucus treatments promoted the dry matter accumulation of maize seedlings. The high concentration of bionic fertilizer and urea treatment reduced the dry matter accumulation of maize seedlings.

The root-shoot ratio is defined as the dry weight ratio of the underground roots of the maize plants to that of above-ground stems and leaves. During the maize seedlings stage, if the root growth was strong, the higher the root-shoot ratio indicates the better crop growth. It can be seen from Figure $4 \mathrm{~d}$ that the lower the liquid fertilizer concentration, the higher the root-shoot ratio. The maize seedlings of root-shoot ratio for bionic fertilizer and urea treatments 1 and 2 were lower than that of CG. Mucus 4, bionic fertilizer4 and urea5 were beneficial to the dry matter accumulation of maize seedlings.

The morphology of maize seedling roots growth is shown in Figure 5. Through the analysis of variance and Duncan's multiple range test [88], the total root length and total root surface area of maize seedlings under the fertilization treatment after complete emergence (14 days after sowing, four-leaf seedling) were investigated.

Effects of different fertilization treatment on the growth of maize roots were evaluated. It can be seen from Supplementary Materials Table S6 that for the total root length of the maize seedlings, the mucus treatments 4 and 5 , and the urea treatments 1 and 2 are significantly different $(p<0.05)$ from the other treatments; Among the treatments, the total root mucus4 treatment was the longest, with an average length of $289.62 \mathrm{~cm}$; the total root length of urea1 treatment was the shortest, with an average length of $121.84 \mathrm{~cm}$. For the total root surface area of maize seedlings, treatment of mucus4 and urea1 showed significant difference $(p<0.05)$ with the other treatments; among them, mucus4 had the highest total root surface area, with an average of $12.35 \mathrm{~cm}^{2}$. The total root surface area of urea1 was the lowest, with an average of $6.94 \mathrm{~cm}^{2}$. Compared with the control, the lower concentration of treatment of mucus 4 was most beneficial to the root growth of 
maize seedling plants, while the higher concentration of treatment urea1 significantly inhibited $(p<0.05)$ the development of maize seedling roots. Zhang et al. [54] evidenced similar results that earthworm mucus significantly enhanced tomato seedlings growth through the hydroponic experiment. The analysis results of root growth were consistent with the statistical results of maize emergence quality. Therefore, within the maize seedling stage, for the treatment of mucus4, the bionic fertilizer 5 and the urea 5 which have lower concentration of active ingredient, have the most significant beneficial effect $(p<0.05)$ on the vigor and emergence quality of maize seeds.

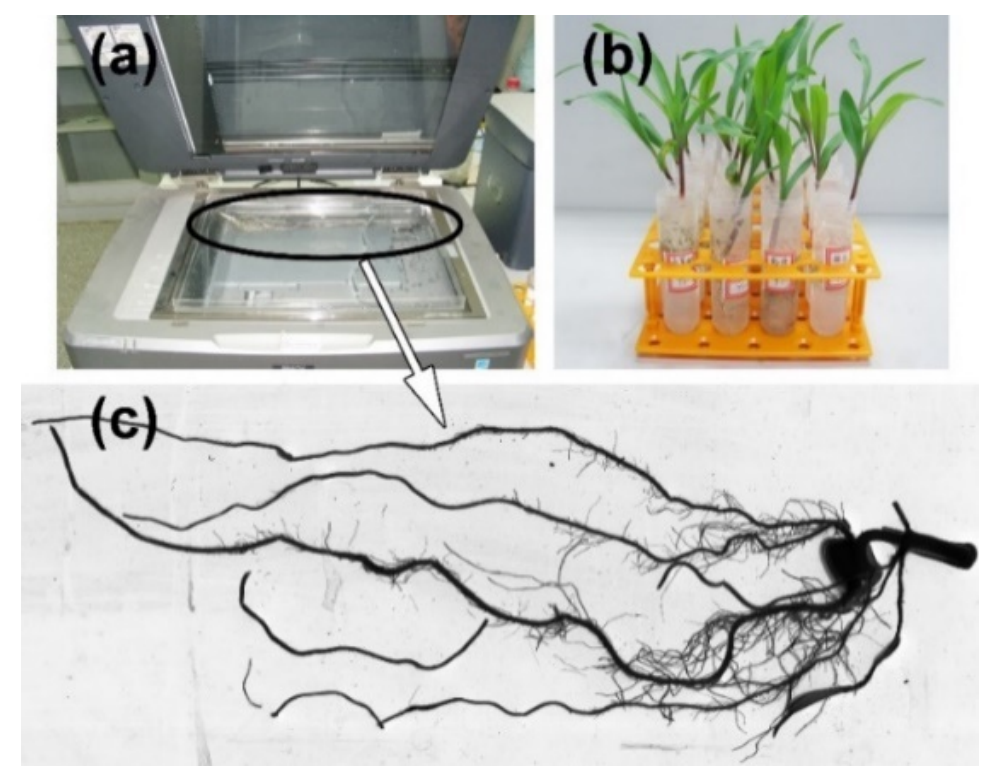

Figure 5. Maize seedlings root analysis. (a) Root washing analysis system; (b) Four-leaf seedling samples; (c) Root morphology analysis.

\subsection{Effects on Soil Nutrients}

Nitrogen is the primary element in soil nutrients that affects maize growth. When nitrogen is sufficient, the plant cell division and growth of maize plants are vigorous. However, when the nitrogen is insufficient, the leaves of the maize plants are weak, and the stems are slender. Conversely, when the nitrogen is excessively applied, the leaves are dark green and in hypertrophy, meanwhile, the stems easily fall. Potassium can increase the absorption and utilization of nitrogen, increase the rate of carbon dioxide assimilation and improve the lodging resistance of maize stalks. Phosphorus is involved in physiological processes such as nitrogen metabolism in maize cells, promoting root development and improving ear quality. Soil $\mathrm{pH}$ affects soil nutrient availability and soil microbial activity and has a direct impact on maize growth quality. Therefore, after nitrogen based liquid fertilizers were applied, the effects of fertilizer on potassium and phosphorus and soil $\mathrm{pH}$ should also be considered.

During the growth stage of maize, the effects of different liquid fertilizer treatments on the content of ammonium nitrogen and rapidly available potassium in the soil are shown in Figure 6. As compared with the CG, liquid fertilizer application treatment increased the nitrogen content in the tested soil. In consequence, more nitrogen nutrition for the soil could be provided. For the five treatments of the same liquid fertilizer, the nitrogen content in the sampled soil with higher concentration of active ingredient was more than that of low concentration treatment and the control group. With the advancing of maize transplanting days, the nitrogen content in the sampled soil gradually decreased. 

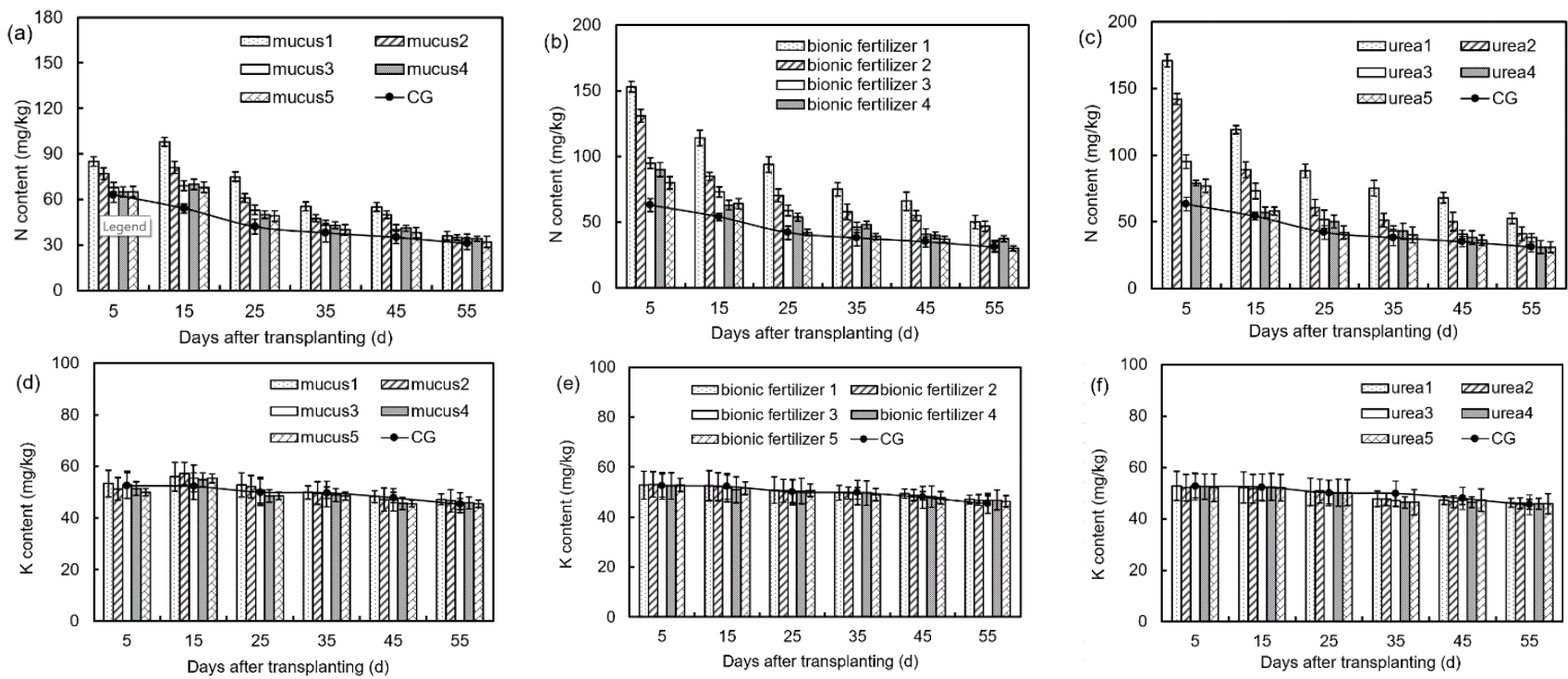

Figure 6. Effect of various treatments of maize long-term liquid fertilizer on nitrogen and potassium in soil. (a-c) Content of ammonium nitrogen in soil; (d-f) Content of rapid available potassium in soil.

It can be observed from Figure 6a-c, after 15 days of transplanting, the nitrogen content in the sampled soil treated by the mucus reached the maximum. While, 5 days after the transplanting, in the sampled soil with the bionic fertilizer and urea treatment, the nitrogen content reached the maximum. The maximum nitrogen content in the high concentration test treatment is shown in Table 4. Earthworm mucus contained numerous available plant nutrient substances, which were propitious to plants absorption and growth [59]. The soil fertilizing effects of the mucus and bionic fertilizer were greatly improved, and the maximum increase of nitrogen content in the sampled soil reached $53.81 \%$ and $140.10 \%$, respectively. The reason for the deviation in nitrogen content on the one hand could be explained that the mucus gradually decomposes and releases nitrogen, and on the other hand, the decomposition activity of humus in the soil was increased. These effects were obvious after mucus was applied to the soil for about 15 days.

Table 4. Three liquid fertilizer fertilization treatments in maize growing stage.

\begin{tabular}{cccc}
\hline $\begin{array}{c}\text { Fertilization } \\
\text { Treatment }\end{array}$ & $\begin{array}{c}\text { Maximum Nitrogen } \\
\text { Content }(\mathbf{m g} / \mathbf{k g})\end{array}$ & $\begin{array}{c}\text { Days after } \\
\text { Transplanting (d) }\end{array}$ & $\begin{array}{c}\text { Maximum Increase in } \\
\text { Nitrogen Content (\%) }\end{array}$ \\
\hline mucus1 & $98.34 \pm 5.62$ & 15 & 53.81 \\
bionic fertilizer1 & $153.43 \pm 4.41$ & 5 & 140.10 \\
urea1 & $171.21 \pm 5.76$ & 5 & 167.96 \\
CG & $63.92 \pm 5.01$ & 5 & - \\
\hline
\end{tabular}

The bionic fertilizer and urea decompose faster, and for bionic fertilizer, the primary component amino acids could be partially absorbed by the maize plants, so the nitrogen content of the urea remaining in the sampled soil was higher than that of bionic fertilizer. It can be seen from Figure $6 \mathrm{~d}-\mathrm{f}$ that after the three types of liquid fertilizers were applied to the soil, the content of rapidly available potassium in the sampled soil decreased slowly with the days after transplanting. The rapidly available potassium content in each fertilization treatment was the same as that in the control. The difference between liquid fertilizer treatments was not significant $(p>0.05)$. At the end of the test, the rapidly available potassium content in the control sampling soil decreased from 52 to $45 \mathrm{mg} / \mathrm{kg}$.

The effect of different liquid fertilizer treatments on the content of rapidly available phosphorus and $\mathrm{pH}$ value in the maize growth stage is shown in Figure 7. The content of available phosphorus in the sampled soil decreased slowly with the growth of maize (Figure 7a-c). Fifteen 
days after transplanting, compared with the CG, the high-concentration mucus1 treatment increased the rapidly available phosphorus content in the sampled soil by $12.3 \%$.
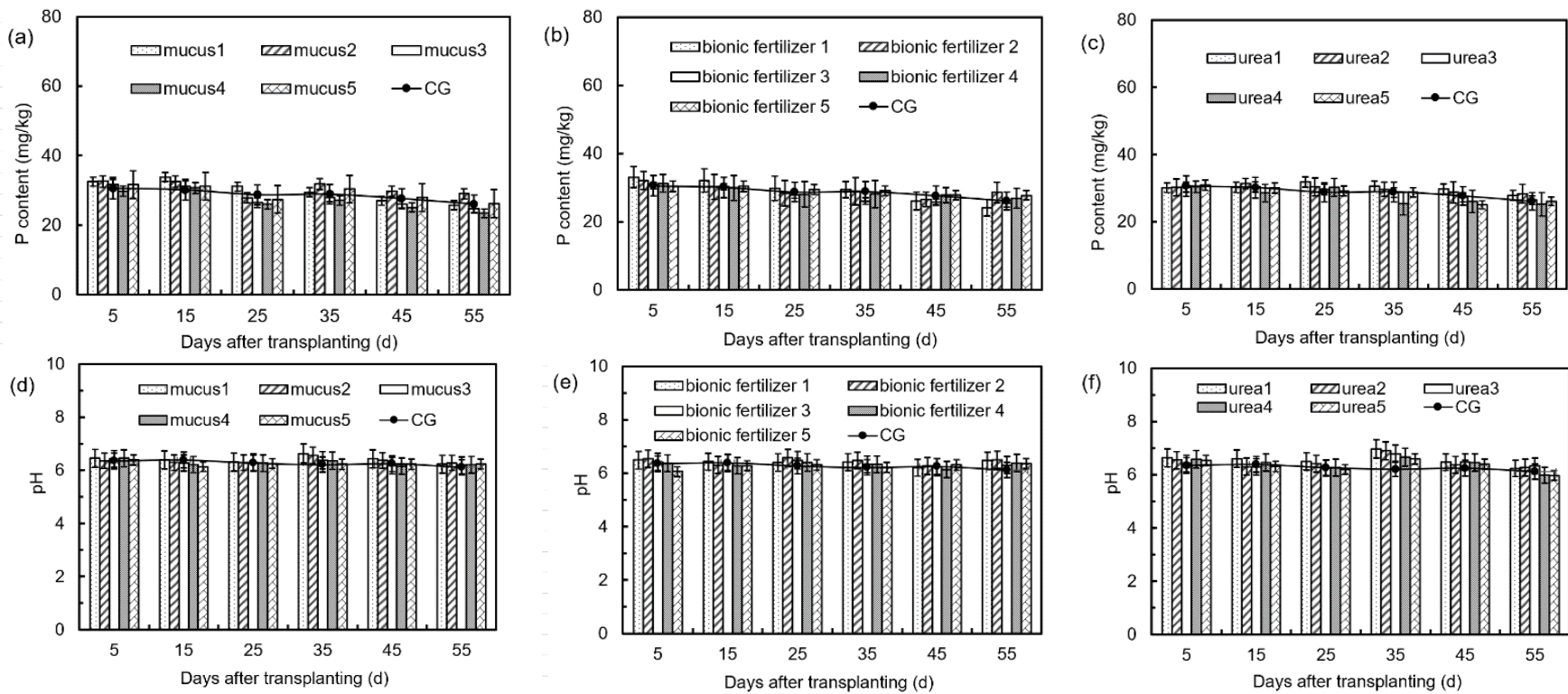

Figure 7. Effect of fertilization treatment on soil phosphorus content and $\mathrm{pH}$ value in the maize growth stage. (a-c) Rapid available phosphorus in soil; $(\mathbf{d}-\mathbf{f})$ Soil $\mathrm{pH}$ value.

At the end of the test stage, the content of rapidly available phosphorus in the sampled soil corresponding to the mucus treatment was reduced from a maximum of 33.8 to $25.7 \mathrm{mg} / \mathrm{kg}$ (Figure $7 \mathrm{~b}$ ). The effect of bionic fertilizer and urea treatment on the phosphorus content in the sampled soil was not significant $(p>0.05)$. The $\mathrm{pH}$ values of the three liquid fertilizers were not significant $(p>0.05)$ in the sampled soil, and the measured $\mathrm{pH}$ value was $6.40 \pm 0.23$ (Figure $7 \mathrm{~d}-\mathrm{f}$ ).

\subsection{Effects on Maize Growth}

The effect of liquid fertilization treatments on maize plant height and stem diameter in maize growth stage is shown in Supplementary Materials Figure S4. As compared with the CG, the three liquid fertilizers significantly promoted $(p<0.05)$ the maize plant height and stem diameter. After 15 days of maize transplanting, the higher concentration liquid fertilizer treatment had more beneficial effects on promoting the maize plant height and stem diameter as compared with that of lower concentration. At the end of the test stage, the effects of three liquid fertilization treatments on the plant height and stem diameter of maize were as follows: bionic fertilizer $>$ urea $>$ mucus $>C G$, and the effect on the plant height and stem diameter of maize are shown in Table 5.

Table 5. Effect of three liquid fertilizer treatments on plant height and stem diameter of maize*.

\begin{tabular}{ccccc}
\hline \multirow{2}{*}{ Treatment } & \multicolumn{2}{c}{ Plant Height } & \multicolumn{2}{c}{ Stem Diameter } \\
\cline { 2 - 5 } & $\begin{array}{c}\text { Measured Value } \\
\mathbf{( c m )}\end{array}$ & $\begin{array}{c}\text { Average } \\
\text { Increase (\%) }\end{array}$ & $\begin{array}{c}\text { Measured Value } \\
\mathbf{( m m )}\end{array}$ & $\begin{array}{c}\text { Average } \\
\text { Increase (\%) }\end{array}$ \\
\hline mucus & $189.47 \pm 6.06$ & 13.48 & $19.91 \pm 0.81$ & 13.07 \\
bionic fertilizer & $198.28 \pm 8.72$ & 18.75 & $21.05 \pm 0.89$ & 19.32 \\
urea & $190.63 \pm 7.85$ & 14.20 & $20.43 \pm 0.76$ & 15.91 \\
control & $166.94 \pm 6.84$ & - & $17.65 \pm 0.65$ & - \\
\hline
\end{tabular}

* The data in the table represent the mean \pm standard deviation of three measurements. 
The nutrient status of maize leaves was closely related to the spectral characteristics. During the maize growth stage, the nutrient status of maize plants could be identified by measuring the variations of spectral on the leaves.

The SPAD (Soil-Plant Analysis Development) value was calculated by the chlorophyll meter is the chlorophyll content per unit area of maize leaves, which can be used to compare the nitrogen content per unit area of maize leaves. In this study, the changes in SPAD values in the leaves of maize seedlings under different liquid fertilization treatments were recorded. The results showed that the SPAD value of maize leaves under high concentration fertilization treatments was higher than that of low concentration treatments. In Figure 8 , the effects of three high-concentration fertilization treatments on the SPAD value of maize leaves were compared. It can be observed that the SPAD value of the leaves gradually increased during the maize growth stage.

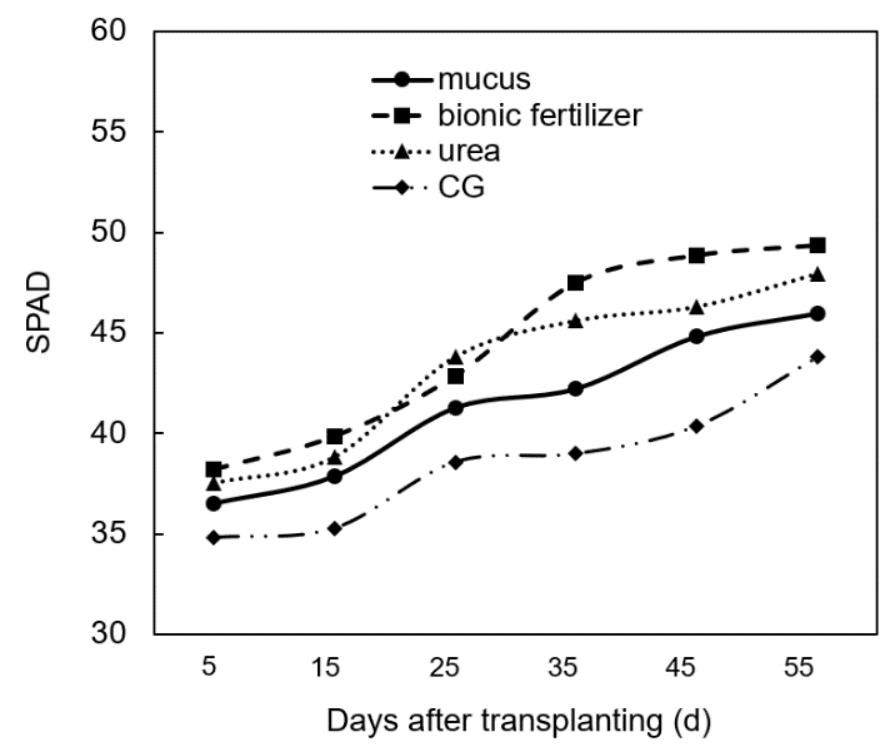

Figure 8. Effect of three high-concentration fertilization treatments on the SPAD (Soil-Plant Analysis Development) value of maize leaves during the maize growth stage.

Within the beginning 5 days of transplanting, as compared with the CG, the fertilized maize leaves showed no significant difference $(p>0.05)$. However, after 25 days of transplanting, the fertilized maize leaves showed a gap in the SPAD value. The fertilized maize leaves reached their peak of SPAD at 55 days after transplanting. The effects of three liquid fertilizers on the SPAD value of maize leaves were: bionic fertilizer $>$ urea $>$ mucus> CG. Under three liquid fertilizer treatments, the SPAD value of maize leaves was consistent with the trend of plant height and stem diameter. This observation indicates that with the growth of maize plants, the nitrogen content in the leaves increased continuously. Moreover, the mucus and bionic fertilizer increased the chlorophyll content of the maize leaves and were beneficial to leaf growth.

Maize synthesizes organic matter through photosynthesis to achieve dry matter accumulation. The photosynthetic characteristics of maize leaves are considered to be positively correlated with grain yield. Adequate photosynthetic characteristics are essential for increasing maize yield. In this study, changes in photosynthetic characteristics of maize during long-term growth under different liquid fertilization treatments were recorded. The results showed that the photosynthetic performances of maize leaves under high concentration fertilization treatment were higher than those of low concentration treatment. In Figure 9, the effects of three high-concentration fertilization treatments on the four types of photosynthetic indexes of maize leaves were compared. The photosynthetic efficiency of maize leaves showed an increasing trend with its growth. Compared with the control, the application of liquid fertilizer significantly increased $(p<0.05)$ the photosynthetic efficiency of maize leaves. Five days after transplanting, the differences in photosynthetic characteris- 
tics of maize leaves under fertilization treatment were not significant $(p>0.05)$. The peaks of $\mathrm{Pn}$ and $\mathrm{Ci}$ in maize leaves were reached 45 days after transplanting. The bionic liquid fertilizer achieved the optimum photosynthetic indexes, for which the peak value of $\mathrm{Pn}$ index was $32.9 \mu \mathrm{mol} \mathrm{CO} \mathrm{m}^{-2} \mathrm{~s}^{-1}$, and the peak value of $\mathrm{Ci}$ index was $557.3 \mu \mathrm{mol} \mathrm{CO} \mathrm{mol}^{-1}$. The peaks of Cond and Trmmol in maize leaves appeared at 55 days after transplanting, the peak value of Cond was $0.94 \mathrm{~mol} \mathrm{H}_{2} \mathrm{O} \mathrm{m}^{-2} \mathrm{~s}^{-1}$, and for Trmmol index was $12.7 \mathrm{mmol}$ $\mathrm{H}_{2} \mathrm{O} \mathrm{m}^{-2} \mathrm{~s}^{-1}$. Fertilization treatments had certain effects on the photosynthetic characteristics of maize leaves during the growth stage, indicating that increasing soil nutrients by liquid fertilizer could increase the photosynthetic rate of maize leaves and promote the dry matter accumulation. The effect of liquid fertilizer on photosynthetic characteristics of maize leaves were ranked as follows: Bionic fertilizer $>$ urea $>$ mucus $>$ CG.
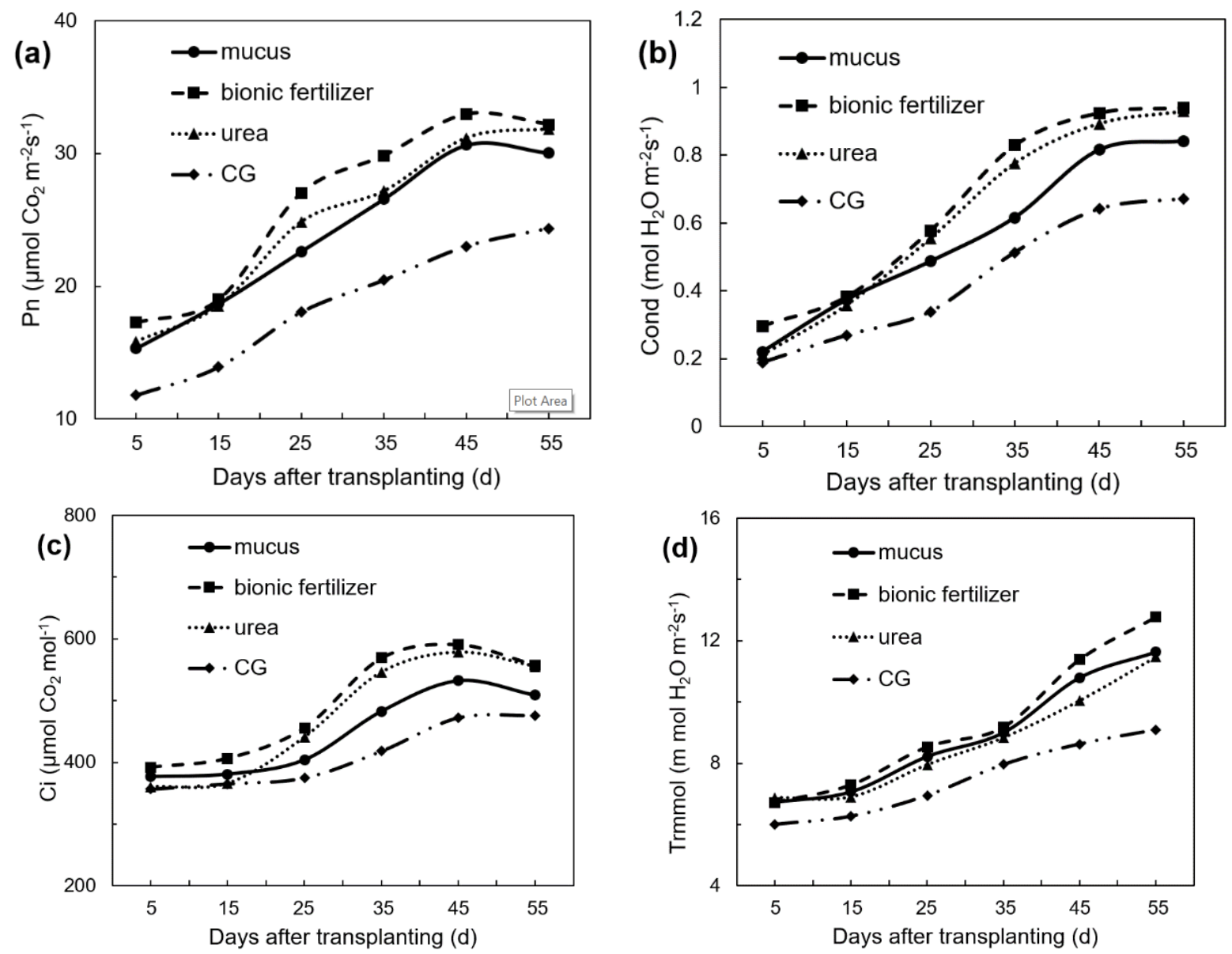

Figure 9. Effects of three liquid fertilizer fertilization treatments on photosynthetic characteristics of maize leaves. (a) Net photosynthetic rate (Pn); (b) Stomatal conductance (Cond); (c) Intercellular $\mathrm{CO}_{2}$ concentration (Ci); (d) Transpiration rate (Trmmol).

\section{Conclusions}

In this study, inspired by the amino acid composition of the Eisenia foetida, bionic fertilizer was designed and prepared. The commonly used urea fertilizer, earthworm mucus (mucus) and its mimicked mixture of the amino acids (bionic fertilizer) were applied to maize to investigate their effects on stimulating maize growth during the seedling and growth stage (distilled water was used as the control group (CG)). From the experimental results, the following conclusions were obtained:

(1) The lower concentration treatments of liquid fertilizers were more beneficial to the improvement of maize seed vigor index than the higher concentration ones. The 
effects of three liquid fertilizers on the emergence rate of maize were ranked as follows: Mucus $>$ bionic fertilizer $>$ urea.

(2) Under lower concentration of bionic and urea fertilizer treatments, the average of plant height and stem diameter after the maize emergence were increased as compared with higher concentration ones. Compared with the CG, lower concentrations of mucus were beneficial to the growth of maize seedling roots, while higher concentrations of urea significantly inhibited $(p<0.05)$ the development of maize seedling roots.

(3) Higher concentration treatments provided more nitrogen nutrition to the soil as compared to that of lower concentrations. The mucus treatment reached the maximum nitrogen content after 15 days of transplanting. While, the bionic fertilizer and urea treatment reached the maximum nitrogen content after 5 days of transplanting. The difference between rapidly available potassium and phosphorus in each fertilization treatment was not significant $(p>0.05)$. Similarly, the effects of three liquid fertilizers on the $\mathrm{pH}$ value in the sampled soil were not significant $(p>0.05)$.

(4) As compared with the CG, the three tested liquid fertilizers significantly promoted $(p<0.05)$ the growth of maize in terms of plant height and stem diameter. At the end of the experimental stage, the effects of three liquid fertilizers on the maize plant height and stem diameter were ranked as follows: bionic fertilizer $>$ urea $>$ mucus $>$ CG.

(5) During the test stage, the SPAD value of maize leaves increased gradually, and the SPAD value of maize leaves reached the peak 55 days after transplanting. The effects of three liquid fertilizers on the SPAD value of maize leaves were ranked as follows: bionic fertilizer $>$ urea $>$ mucus $>$ CG.

(6) During the growing stage of maize plants, mucus and bionic fertilizer increased the chlorophyll content of maize leaves, which was beneficial to increase nitrogen content. The application of liquid fertilizer increased the photosynthetic rate of maize leaves and promoted the accumulation of dry matter in maize. The effects of liquid fertilizer on photosynthetic characteristics of maize leaves were ranked as follows: bionic fertilizer $>$ urea $>$ mucus $>$ CG.

Compared with available literatures, the main novelty this study provides is an innovative bionic approach for developing effective liquid fertilizer by learning from nature. This study indicated that both of the extracted mucus and bionic fertilizer were found to promote the maize plant physiology, such as the emergence rate, plant height and stem diameter in comparison to urea treatment. Moreover, bionic fertilizer enhances the photosynthesis capability of maize, and demonstrated significant beneficial $(p<0.05)$ fertilizing effects, which increased soil nutrients, improved maize physiological parameters, promoted its growth and improved dry matter accumulation. These results verified the effectiveness of bionic fertilizer on stimulating maize growth. Further research is required on the physical and biological effects of bionic fertilizer on nutrient supply, so that suitable fertilizer application practices can be developed to optimize the beneficial effects of bionic fertilizer on soil fertility.

Supplementary Materials: The following are available online at https:/ /www.mdpi.com/article/ 10.3390/su13084299/s1, Table S1: Proportion of amino acid in epidermal mucus of Eisenia fetida, Table S2: Nitrogen content of amino acids in mucus of Eisenia fetida, Figure S1: Maize sowing and emergence standards. (a) Apply liquid fertilizer to the nursery; (b) Maize seedlings with the height of $2 \mathrm{~cm}$ were used as the emergence standard, Table S3: Physical properties and nutrient content of greenhouse soil, Table S4: Liquid fertilizers application protocol, Table S5: Three types of liquid fertilizer fertilization treatment within maize growth stage. Figure S2: Maize growth index test. (a) Portable photosynthetic apparatus; (b) Soil nutrient meter; (c) Chlorophyll meter; (d) Maize growth measurement, Figure S3. Effect of liquid fertilizer treatments on maize emergence rate and emergence index. (a-e) Maize emergence rate of 9-13 days after sowing; (f) Emergence index, Table S6. Analysis of root growth morphology of maize seedlings. 
Author Contributions: Conceptualization, D.Z. and Y.W.; methodology, D.Z.; software, Z.Z.; validation, Z.Z., Y.W. and D.Z.; formal analysis, Z.Z.; investigation, D.Z.; resources, D.Z.; data curation, Z.Z. and D.Z.; writing—original draft preparation, Z.Z. and D.Z.; writing—review and editing, V.K.T. and D.Z.; visualization, Z.Z and V.K.T.; supervision, Z.Z. and D.Z.; project administration, D.Z.; funding acquisition, Z.Z. and D.Z. All authors have read and agreed to the published version of the manuscript.

Funding: This research was funded by National Natural Science Foundation of China, grant number 52065031, 51805356, 51605210; byAnalysis and Testing Foundation Project of Kunming University of Science and Technology grant number 2019T20140038, 2019M20182214012, 2019M20182214014.

Institutional Review Board Statement: Not applicable.

Data Availability Statement: All data included in this study are available upon request by contact with the corresponding author.

Acknowledgments: The authors acknowledge invaluable administrative, theoretical and technical assistance from Jin Tong, Donghui Chen and Yunhai Ma.

Conflicts of Interest: The authors declare no conflict of interest. The funders had no role in the design of the study; in the collection, analyses, or interpretation of data; in the writing of the manuscript, or in the decision to publish the results.

\section{References}

1. Foley, J.A.; Ramankutty, N.; Brauman, K.A.; Cassidy, E.S.; Gerber, J.S.; Johnston, M.; Mueller, N.D.; O'Connell, C.; Ray, D.K.; West, P.C.; et al. Solutions for a cultivated planet. Nature 2011, 478, 337-342. [CrossRef]

2. He, Z.; Shang, X.; Zhang, T. Study on Water Saving Potential and Net Profit of Zea mays L.: The Role of Surface Mulching with Micro-Spray Irrigation. Appl. Sci. 2020, 10, 402. [CrossRef]

3. Laucka, A.; Andriukaitis, D.; Valinevicius, A.; Navikas, D.; Zilys, M.; Markevicius, V.; Klimenta, D.; Sotner, R.; Jerabek, J. Method for Volume of Irregular Shape Pellets Estimation Using 2D Imaging Measurement. Appl. Sci. 2020, 10, 2650. [CrossRef]

4. Sweeney, D.W.; Ruiz-Diaz, D.; Jardine, D.J. Nitrogen Management and Uptake by Corn on No-Till and Ridge-Till Claypan Soil. Agrosyst. Geosci. Environ. 2018, 1, 180034. [CrossRef]

5. Omar, L.; Ahmed, O.H.; Jalloh, M.B.; Nik Muhamad, A.M. Soil Nitrogen Fractions, Nitrogen Use Efficiency and Yield of Zea mays L. Grown on a Tropical Acid Soil Treated with Composts and Clinoptilolite Zeolite. Appl. Sci. 2020, 10, 4139. [CrossRef]

6. Matlok, N.; Szostek, M.; Antos, P.; Gajdek, G.; Gorzelany, J.; Bobrecka-Jamro, D.; Balawejder, M. Effect of Foliar and Soil Fertilization with New Products Based on Calcinated Bones on Selected Physiological Parameters of Maize Plants. Appl. Sci. 2020, 10, 2579. [CrossRef]

7. Gao, J.; Zhang, J.; Zhang, F.; Hou, Z.; Zhai, Y.; Ge, L. Analysis of Movement Law and Influencing Factors of Hill-Drop Fertilizer Based on SPH Algorithm. Appl. Sci. 2020, 10, 1643. [CrossRef]

8. Shiferaw, B.; Prasanna, B.M.; Hellin, J.; Bänziger, M. Crops that feed the world 6. Past successes and future challenges to the role played by maize in global food security. Food Secur. 2011, 3, 307. [CrossRef]

9. Domínguez, J.; Bohlen, P.J.; Parmelee, R.W. Earthworms Increase Nitrogen Leaching to Greater Soil Depths in Row Crop Agroecosystems. Ecosystems 2004, 7, 672-685. [CrossRef]

10. Rüdisser, J.; Tasser, E.; Peham, T.; Meyer, E.; Tappeiner, U. Hidden Engineers and Service Providers: Earthworms in Agricultural Land-Use Types of South Tyrol, Italy. Sustainability 2021, 13, 312. [CrossRef]

11. Wen, S.; Shao, M.a.; Wang, J. Earthworm Burrowing Activity and Its Effects on Soil Hydraulic Properties under Different Soil Moisture Conditions from the Loess Plateau, China. Sustainability 2020, 12, 9303. [CrossRef]

12. Medina-Sauza, R.M.; Álvarez-Jiménez, M.; Delhal, A.; Reverchon, F.; Blouin, M.; Guerrero-Analco, J.A.; Cerdán, C.R.; Guevara, R.; Villain, L.; Barois, I. Earthworms Building Up Soil Microbiota, a Review. Front. Environ. Sci. 2019, 7, 81. [CrossRef]

13. Wurst, S.; Gebhardt, K.; Rillig, M.C. Independent effects of arbuscular mycorrhiza and earthworms on plant diversity and newcomer plant establishment. J. Veg. Sci. 2011, 22, 1021-1030. [CrossRef]

14. Ma, L.; Shao, M.a.; Li, T. Characteristics of Soil Moisture and Evaporation under the Activities of Earthworms in Typical Anthrosols in China. Sustainability 2020, 12, 6603. [CrossRef]

15. Dulaurent, A.-M.; Daoulas, G.; Faucon, M.-P.; Houben, D. Earthworms (Lumbricus terrestris L.) Mediate the Fertilizing Effect of Frass. Agronomy 2020, 10, 783. [CrossRef]

16. Dekemati, I.; Simon, B.; Bogunovic, I.; Kisic, I.; Kassai, K.; Kende, Z.; Birkás, M. Long Term Effects of Ploughing and Conservation Tillage Methods on Earthworm Abundance and Crumb Ratio. Agronomy 2020, 10, 1552. [CrossRef]

17. Kanianska, R.; Jad'ud'ová, J.; Makovníková, J.; Kizeková, M. Assessment of Relationships between Earthworms and Soil Abiotic and Biotic Factors as a Tool in Sustainable Agricultural. Sustainability 2016, 8, 906. [CrossRef]

18. Griffiths, B.S.; Faber, J.; Bloem, J. Applying Soil Health Indicators to Encourage Sustainable Soil Use: The Transition from Scientific Study to Practical Application. Sustainability 2018, 10, 3021. [CrossRef] 
19. Darwin, C. The Formation of Vegetable Mould through the Action of Worms: With Observations on Their Habits; Appleton: New York, NY, USA, 1892; Volume 37.

20. Syers, J.K.; Springett, J.A. Earthworms and soil fertility. In Biological Processes and Soil Fertility; Tinsley, J., Darbyshire, J.F., Eds.; Springer: Dordrecht, The Netherlands, 1984; pp. 93-104. [CrossRef]

21. Angst, G.; Mueller, C.W.; Prater, I.; Angst, Š.; Frouz, J.; Jílková, V.; Peterse, F.; Nierop, K.G.J. Earthworms act as biochemical reactors to convert labile plant compounds into stabilized soil microbial necromass. Commun. Biol. 2019, 2, 441. [CrossRef]

22. Curry, J.P.; Schmidt, O. The feeding ecology of earthworms-A review. Pedobiologia 2007, 50, 463-477. [CrossRef]

23. Edwards, C.A. Earthworm Ecology; CRC Press: Boca Raton, FL, USA, 2004.

24. Phillips, H.R.P.; Guerra, C.A.; Bartz, M.L.C.; Briones, M.J.I.; Brown, G.; Crowther, T.W.; Ferlian, O.; Gongalsky, K.B.; van den Hoogen, J.; Krebs, J.; et al. Global distribution of earthworm diversity. Science 2019, 366, 480. [CrossRef]

25. Sizmur, T.; Richardson, J. Earthworms accelerate the biogeochemical cycling of potentially toxic elements: Results of a metaanalysis. Soil Biol. Biochem. 2020, 148, 107865. [CrossRef]

26. Pey, B.; Cortet, J.; Watteau, F.; Cheynier, K.; Schwartz, C. Structure of earthworm burrows related to organic matter of a constructed Technosol. Geoderma 2013, 202-203, 103-111. [CrossRef]

27. Xiang, H.; Guo, L.; Zhang, J.; Zhao, B.; Wei, H. In Situ Earthworm Breeding to Improve Soil Aggregation, Chemical Properties, and Enzyme Activity in Papayas. Sustainability 2018, 10, 1193. [CrossRef]

28. Lubbers, I.M.; Brussaard, L.; Otten, W.; Van Groenigen, J.W. Earthworm-induced N mineralization in fertilized grassland increases both N2O emission and crop-N uptake. Eur. J. Soil Sci. 2011, 62, 152-161. [CrossRef]

29. Mokgophi, M.M.; Manyevere, A.; Ayisi, K.K.; Munjonji, L. Characterisation of Chamaecytisus tagasaste, Moringa oleifera and Vachellia karroo Vermicomposts and Their Potential to Improve Soil Fertility. Sustainability 2020, 12, 9305. [CrossRef]

30. Blanchart, E.; Lavelle, P.; Braudeau, E.; Le Bissonnais, Y.; Valentin, C. Regulation of soil structure by geophagous earthworm activities in humid savannas of Cote d'Ivoire. Soil Biol. Biochem. 1997, 29, 431-439. [CrossRef]

31. Bohlen, P.J.; Parmelee, R.W.; Blair, J.M. Integrating the Effects of Earthworms on Nutrient Cycling across Spatial and Temporal Scales; CRC Press: Boca Raton, FL, USA, 2004; pp. 161-180.

32. Jjagwe, J.; Chelimo, K.; Karungi, J.; Komakech, A.J.; Lederer, J. Comparative Performance of Organic Fertilizers in Maize (Zea mays L.) Growth, Yield, and Economic Results. Agronomy 2020, 10, 69. [CrossRef]

33. Fonte, S.J.; Quintero, D.C.; Velásquez, E.; Lavelle, P. Interactive effects of plants and earthworms on the physical stabilization of soil organic matter in aggregates. Plant Soil 2012, 359, 205-214. [CrossRef]

34. Pulido Moncada, M.; Gabriels, D.; Lobo, D.; Rey, J.C.; Cornelis, W.M. Visual field assessment of soil structural quality in tropical soils. Soil Tillage Res. 2014, 139, 8-18. [CrossRef]

35. Dobson, A.M.; Blossey, B.; Richardson, J.B. Invasive earthworms change nutrient availability and uptake by forest understory plants. Plant Soil 2017, 421, 175-190. [CrossRef]

36. Rodríguez, M.P.; Domínguez, A.; Moreira Ferroni, M.; Wall, L.G.; Bedano, J.C. The Diversification and Intensification of Crop Rotations under No-Till Promote Earthworm Abundance and Biomass. Agronomy 2020, 10, 919. [CrossRef]

37. Li, Y.; Shao, M.; Wang, J.; Li, T. Effects of Earthworm Cast Application on Water Evaporation and Storage in Loess Soil Column Experiments. Sustainability 2020, 12, 3112. [CrossRef]

38. Brussaard, L.; Pulleman, M.M.; Ouédraogo, É.; Mando, A.; Six, J. Soil fauna and soil function in the fabric of the food web. Pedobiologia 2007, 50, 447-462. [CrossRef]

39. Marichal, R.; Mathieu, J.; Couteaux, M.M.; Mora, P.; Roy, J.; Lavelle, P. Earthworm and microbe response to litter and soils of tropical forest plantations with contrasting C:N:P stoichiometric ratios. Soil Biol. Biochem. 2011, 43, 1528-1535. [CrossRef]

40. Nguyen Tu, T.T.; Vidal, A.; Quénéa, K.; Mendez-Millan, M.; Derenne, S. Influence of earthworms on apolar lipid features in soils after 1 year of incubation. Biogeochemistry 2020, 147, 243-258. [CrossRef]

41. Puga-Freitas, R.; Barot, S.; Taconnat, L.; Renou, J.-P.; Blouin, M. Signal Molecules Mediate the Impact of the Earthworm Aporrectodea caliginosa on Growth, Development and Defence of the Plant Arabidopsis thaliana. PLoS ONE 2012, 7, e49504. [CrossRef] [PubMed]

42. Hamamoto, T.; Uchida, Y. The Role of Different Earthworm Species (Metaphire Hilgendorfi and Eisenia Fetida) on $\mathrm{CO}_{2}$ Emissions and Microbial Biomass during Barley Decomposition. Sustainability 2019, 11, 6544. [CrossRef]

43. Laossi, K.-R.; Ginot, A.; Noguera, D.C.; Blouin, M.; Barot, S. Earthworm effects on plant growth do not necessarily decrease with soil fertility. Plant Soil 2010, 328, 109-118. [CrossRef]

44. Eisenhauer, N.; Scheu, S. Earthworms as drivers of the competition between grasses and legumes. Soil Biol. Biochem. 2008, 40, 2650-2659. [CrossRef]

45. Milleret, R.; Le Bayon, R.-C.; Gobat, J.-M. Root, mycorrhiza and earthworm interactions: Their effects on soil structuring processes, plant and soil nutrient concentration and plant biomass. Plant Soil 2009, 316, 1-12. [CrossRef]

46. Jjagwe, J.; Komakech, A.J.; Karungi, J.; Amann, A.; Wanyama, J.; Lederer, J. Assessment of a Cattle Manure Vermicomposting System Using Material Flow Analysis: A Case Study from Uganda. Sustainability 2019, 11, 5173. [CrossRef]

47. Whalen, J.K.; Parmelee, R.W.; Subler, S. Quantification of nitrogen excretion rates for three lumbricid earthworms using 15 N. Biol. Fertil. Soils 2000, 32, 347-352. [CrossRef]

48. Bhadauria, T.; Ramakrishnan, P. Role of earthworms in nitrogen cycling during the cropping phase of shifting agriculture (Jhum) in north-east India. Biol. Fertil. Soils 1996, 22, 350-354. [CrossRef] 
49. Ll, H.; Li, X.; Dou, Z.; Zhang, J.; Wang, C. Earthworm (Aporrectodeatrapezoides)-mycorrhiza (Glomus intraradices) interaction and nitrogen and phosphorus uptake by maize. Biol. Fertil. Soils 2012, 48, 75-85. [CrossRef]

50. Ortiz-Ceballos, A.I.; Peña-Cabriales, J.J.; Fragoso, C.; Brown, G.G. Mycorrhizal colonization and nitrogen uptake by maize: Combined effect of tropical earthworms and velvetbean mulch. Biol. Fertil. Soils 2007, 44, 181-186. [CrossRef]

51. Li, Y.; Wang, S.; Lu, M.; Zhang, Z.; Chen, M.; Li, S.; Cao, R. Rhizosphere interactions between earthworms and arbuscular mycorrhizal fungi increase nutrient availability and plant growth in the desertification soils. Soil Tillage Res. 2019, 186, 146-151. [CrossRef]

52. Heredia, R.B.; Dueñas, S.; Castillo, L.; Ventura, J.J.; Silva Briano, M.; Posadas del Rio, F.; Rodríguez, M.G. Autofluorescence as a tool to study mucus secretion in Eisenia foetida. Comp. Biochem. Physiol. Part A Mol. Integr. Physiol. 2008, 151, 407-414. [CrossRef]

53. Zhang, D.; Chen, Y.; Ma, Y.; Guo, L.; Sun, J.; Tong, J. Earthworm epidermal mucus: Rheological behavior reveals drag-reducing characteristics in soil. Soil Tillage Res. 2016, 158, 57-66. [CrossRef]

54. Zhang, S.; Tang, C.; Li, H.; Wei, Z.; Hu, F. Earthworm Mucus Enhanced Cadmium Accumulation of Tomato Seedlings. Int. J. Phytoremediation 2009, 12, 24-33. [CrossRef]

55. Chen, Y.; Zhang, Q.; Zhang, Y.; Chen, J.; Zhang, D.; Tong, J. Changes in fibrolytic enzyme activity during vermicomposting of maize stover by an anecic earthworm Amynthas hupeiensis. Polym. Degrad. Stab. 2015, 120, 169-177. [CrossRef]

56. Chen, Y.; Zhang, Y.; Zhang, Q.; Xu, L.; Li, R.; Luo, X.; Zhang, X.; Tong, J. Earthworms modify microbial community structure and accelerate maize stover decomposition during vermicomposting. Environ. Sci. Pollut. Res. 2015, 22, 17161-17170. [CrossRef] [PubMed]

57. Bityutskii, N.P.; Maiorov, E.I.; Orlova, N.E. The priming effects induced by earthworm mucus on mineralization and humification of plant residues. Eur. J. Soil Biol. 2012, 50, 1-6. [CrossRef]

58. Guhra, T.; Stolze, K.; Schweizer, S.; Totsche, K.U. Earthworm mucus contributes to the formation of organo-mineral associations in soil. Soil Biol. Biochem. 2020, 145, 107785. [CrossRef]

59. Zhang, S.; Hu, F.; Li, H. Effects of earthworm mucus and amino acids on cadmium subcellular distribution and chemical forms in tomato seedlings. Bioresour. Technol. 2009, 100, 4041-4046. [CrossRef] [PubMed]

60. Pratelli, R.; Voll, L.M.; Horst, R.J.; Frommer, W.B.; Pilot, G. Stimulation of Nonselective Amino Acid Export by Glutamine Dumper Proteins. Plant Physiol. 2010, 152, 762. [CrossRef] [PubMed]

61. Padgett, P.E.; Leonard, R.T. Regulation of nitrate uptake by amino acids in maize cell suspension culture and intact roots. Plant Soil 1993, 155, 159-161. [CrossRef]

62. Khan, S.; Yu, H.J.; Li, Q.; Gao, Y.N.; Sallam, B.N.; Wang, H.; Liu, P.; Jiang, W.J. Exogenous Application of Amino Acids Improves the Growth and Yield of Lettuce by Enhancing Photosynthetic Assimilation and Nutrient Availability. Agronomy $2019,9,266$. [CrossRef]

63. Qiu, X.-M.; Sun, Y.-Y.; Ye, X.-Y.; Li, Z.-G. Signaling Role of Glutamate in Plants. Front. Plant Sci. 2020, 10, 1743. [CrossRef]

64. Teixeira, W.F.; Fagan, E.B.; Soares, L.H.; Soares, J.N.; Reichardt, K.; Neto, D.D. Seed and Foliar Application of Amino Acids Improve Variables of Nitrogen Metabolism and Productivity in Soybean Crop. Front. Plant Sci. 2018, 9, 396. [CrossRef]

65. Garczyńska, M.; Kostecka, J.; Pączka, G.; Hajduk, E.; Mazur-Pączka, A.; Butt, K.R. Properties of Vermicomposts Derived from Cameroon Sheep Dung. Appl. Sci. 2020, 10, 5048. [CrossRef]

66. Ren, L.; Liang, Y. Biological couplings: Classification and characteristic rules. Sci. China Technol. Sci. 2009, 52, 2791-2800. [CrossRef]

67. Ren, L.; Liang, Y. Preliminary studies on the basic factors of bionics. Sci. China Technol. Sci. 2014, 57, 520-530. [CrossRef]

68. Ren, L. Progress in the bionic study on anti-adhesion and resistance reduction of terrain machines. Sci. China Technol. Sci. 2009, 52, 273-284. [CrossRef]

69. Ren, L.; Liang, Y. Biological couplings: Function, characteristics and implementation mode. Sci. China Technol. Sci. 2010, 53, 379-387. [CrossRef]

70. Ren, L.; Liang, Y. Coupling Bionics; Science Press: Beijing, China, 2011.

71. Zu, Y.Q.; Yan, Y.Y. Numerical simulation of electroosmotic flow near earthworm surface. J. Bionic Eng. 2006, 3, 179-186. [CrossRef]

72. Khan, M.A.; Qaisrani, R.; Li, J.-Q. The techniques of reducing adhesion and scouring soil by bionic-review of literature. Adv. Nat. Sci. 2010, 3, 41-50.

73. Song, C.-W.; Lee, D.-J.; Lee, S.-Y. Bioinspired segment robot with earthworm-like plane locomotion. J. Bionic Eng. 2016, 13, 292-302. [CrossRef]

74. Li, J.; Kou, B.; Liu, G.; Fan, W.; Liu, L. Resistance reduction by bionic coupling of the earthworm lubrication function. Sci. China Technol. Sci. 2010, 53, 2989-2995. [CrossRef]

75. Ren, L.; Cong, Q.; Tong, J.; Chen, B. Reducing adhesion of soil against loading shovel using bionic electro-osmosis method. J. Terramechanics 2001, 38, 211-219. [CrossRef]

76. Gu, Y.Q.; Fan, T.X.; Mou, J.G.; Jiang, L.F.; Wu, D.H.; Zheng, S.H. A review of bionic technology for drag reduction based on analysis of abilities the earthworm. Int. J. Eng. Res. Afr. 2016, 19, 103-111. [CrossRef]

77. Vincent, J.F. Biomimetic materials. J. Mater. Res. 2008, 23, 3140-3147. [CrossRef]

78. El-Ghamry, A.M.; El-Hai, K.A.; Ghoneem, K.M. Amino and humic acids promote growth, yield and disease resistance of faba bean cultivated in clayey soil. Aust. J. Basic Appl. Sci. 2009, 3, 731-739. 
79. Shehata, S.; Gharib, A.; El-Mogy, M.M.; Gawad, A.; Shalaby, E.A. Influence of compost, amino and humic acids on the growth, yield and chemical parameters of strawberries. J. Med. Plants Res. 2011, 5, 2304-2308.

80. Neuhauser, E.; Loehr, R.; Milligan, D.; Malecki, M. Toxicity of metals to the earthworm Eisenia fetida. Biol. Fertil. Soils 1985, 1, 149-152. [CrossRef]

81. Raza, S.T.; Tang, J.L.; Ali, Z.; Yao, Z.; Bah, H.; Iqbal, H.; Ren, X. Ammonia Volatilization and Greenhouse Gases Emissions during Vermicomposting with Animal Manures and Biochar to Enhance Sustainability. Int. J. Environ. Res. Public Health 2021, 18, 178. [CrossRef]

82. Wen, B.; Liu, Y.; Hu, X.-Y.; Shan, X.-Q. Effect of earthworms (Eisenia fetida) on the fractionation and bioavailability of rare earth elements in nine Chinese soils. Chemosphere 2006, 63, 1179-1186. [CrossRef]

83. Sun, J.; Gao, J.; Wang, Z.; Hu, S.; Zhang, F.; Bao, H.; Fan, Y. Maize Canopy Photosynthetic Efficiency, Plant Growth, and Yield Responses to Tillage Depth. Agronomy 2019, 9, 3. [CrossRef]

84. Shen, D.; Zhang, G.; Xie, R.; Ming, B.; Hou, P.; Xue, J.; Li, S.; Wang, K. Improvement in Photosynthetic Rate and Grain Yield in Super-High-Yield Maize (Zea mays L.) by Optimizing Irrigation Interval under Mulch Drip Irrigation. Agronomy 2020, 10, 1778. [CrossRef]

85. Wang, D.; Li, G.; Mo, Y.; Cai, M.; Bian, X. Effect of Planting Date on Accumulated Temperature and Maize Growth under Mulched Drip Irrigation in a Middle-Latitude Area with Frequent Chilling Injury. Sustainability 2017, 9, 1500. [CrossRef]

86. Li, Y.; Huang, G.; Guo, Y.; Zhou, Y.; Duan, L. Coronatine Enhances Stalk Bending Resistance of Maize, Thickens the Cell Wall and decreases the Area of the Vascular Bundles. Agronomy 2020, 10, 807. [CrossRef]

87. Wong, L.K. Effects of Secretions of the Mucus Gland of Sirex Noctilio on Biochemical Systems in Pinus Radiata, and some Physicochemical Properties of the Mucus. Ph.D. Thesis, University of Tasmania, Hobart, Australia, 1977.

88. Chapman, J.; Truong, V.K.; Elbourne, A.; Gangadoo, S.; Cheeseman, S.; Rajapaksha, P.; Latham, K.; Crawford, R.J.; Cozzolino, D. Combining Chemometrics and Sensors: Toward New Applications in Monitoring and Environmental Analysis. Chem. Rev. 2020, 102, 6048-6069. [CrossRef] [PubMed] 